\title{
Climatic and environmental change in Africa during the last two centuries
}

\author{
Sharon E. Nicholson* \\ Department of Meteorology, Florida State University, Tallahassee, Florida 32306, USA
}

\begin{abstract}
Climatic and environmental changes in Africa during the last 2 centuries have been examined, using both systematic rainfall records and proxy information concerning lakes and rivers and the occurrence of famine and drought. The rainfall records provide excellent detail for the 20th century. The proxy data have been used to produce a semi-quantitative data set spanning most of the continent and having an annual time resolution. These provide an overview of conditions during the 19th century. Various issues related to the causes of these 2 centuries of variability are also considered: atmospheric and oceanic processes, desertification, surface albedo, mineral dust and hydrological feedbacks. The most significant climatic change that has occurred has been a long-term reduction in rainfall in the semi-arid regions of West Africa. This was on the order of 20 to $40 \%$ in parts of the Sahel. There have been 3 decades of protracted aridity. Nearly all of Africa has been affected by increased aridity, particularly since the 1980s. Few changes in temperature have been demonstrated. These have occurred on a much smaller scale and are of considerably lower magnitude than those over the continents. The rainfall conditions over Africa during the last 2 to 3 decades are not unprecedented. A similar dry episode prevailed during most of the first half of the 19th century. By mid-century, conditions more typical of the 'normal' for the current century again prevailed. Thus, the 3 decades of dry conditions evidenced in the Sahel are not in themselves evidence of irreversible global change. On the other hand, the processes controlling rainfall over most of the continent are now reasonably well understood. One of the most important factors, particularly in the Sahel, is sea-surface temperatures. It has been hypothesized that anthropogenic changes in the land surface, particularly land use change and desertification, have contributed significantly to the decline in rainfall. Current evidence suggests that if changes in the land surface (e.g., vegetation cover, surface albedo, soil moisture) signficantly impact climate, they are much more strongly controlled by natural climate variations, such as the recent decline in rainfall, than by human-induced land-use change or degradation. Unfortunately, we still do not have any accurate large-scale assessments of the extent, nature and degree of such changes. The dreaded 'desertification' process appears to be confined to relatively small scales. However, there is still cause for concern because the net effect of the various feedback processes involved in land degradation appears to be destabilization of ecosystems. Thus, a priority must be large-scale monitoring of the land surface and estimates of the degree of change.
\end{abstract}

KEY WORDS: Africa $\cdot$ Climate $\cdot$ Rainfall $\cdot$ Environment Resale or republication not permitted without written consent of the publisher

\section{INTRODUCTION}

Africa is one of the world's largest continents, covering over 30 million $\mathrm{km}^{2}$ and including over 45 countries. The region's environment is closely linked with

*E-mail: sen@met.fsu.edu its climate, so that climatic constraints have been a major force in the development of vegetation, soils, agriculture and general livelihood. This article summarizes what is known about African climate and environment during the past 2 centuries. It will commence with a discussion of regional climate, then continue with historical climate reconstruction for the 19th century, based on proxy and actual data. Then trends of 
rainfall observed instrumentally during the 20th century will be described. This material will be synthesized into a general climatic chronology for the continent and will be evaluated in the context of global climatic history. Finally, the processes involved in producing these long-term trends will be examined. This will include a discussion both of meteorological factors governing African climate variability and of hypothesized land-surface effects, such as land-use change, desertification, the albedo question and dust. For a more thorough review of the climatic issues related to land-surface processes, one is referred to Nicholson (2000a) and Nicholson et al. (1998).

Because environmental changes in Africa are most directly related to rainfall, only this aspect of climate will be stressed. Also, most papers dealing with climatic change over Africa have been limited to studies of rainfall. Other issues, such as temperature changes, influences of climate change on hydrology, and so on, are dealt with in other papers in this CR SPECIAL (e.g., Feddema 2001, Hulme et al. 2001). For information on long-term temperature changes, one is also referred to papers by Jones et al. (1986a,b, 1999), the 1995 IPCC Report (Nicholls et al. 1996), Hulme (1992), Hastenrath (1984), Hastenrath \& Kruss (1992), Easterling et al. (1997) and Jones \& Lindesay (1993). For further information on hydrologic changes, one is referred to Sutcliffe \& Knott (1987), Walling (1996), and Farquharson \& Sutcliffe (1998).

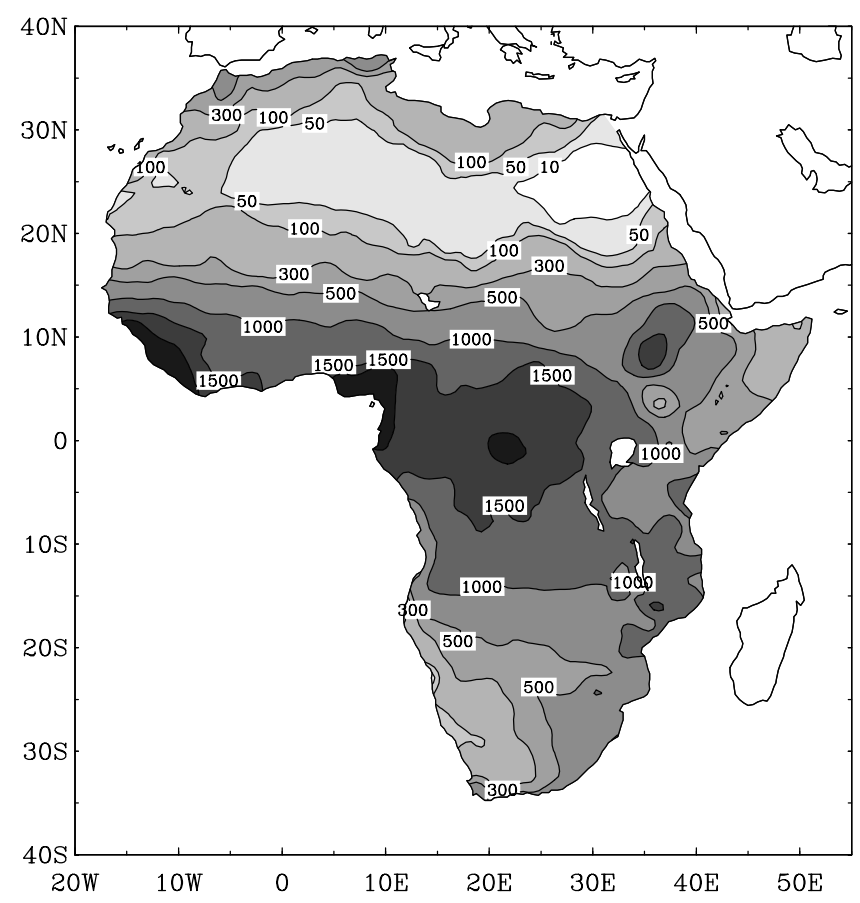

Fig. 1. Mean annual rainfall (mm) over Africa

\section{CLIMATIC BACKGROUND}

Most of Africa lies in tropical and subtropical latitudes, where temperatures are high throughout the year and vary more from daytime to nighttime than during the course of the year. The diurnal range is about 10 to $15^{\circ} \mathrm{C}$, except in the deserts. The annual range is less than $6^{\circ} \mathrm{C}$ over a third of the continent and in most areas south of the Sahara it does not exceed about $10^{\circ} \mathrm{C}$. Temperatures are also relatively constant from year to year except in the highest latitudes. A true cold season occurs only on the poleward extremes of the continent (north of the Sahara and limited areas of southern Africa).

An extreme range of climates spans the continent. Mean annual rainfall ranges from less than $1 \mathrm{~mm} \mathrm{yr}^{-1}$ in parts of the Sahara to over $5000 \mathrm{~mm} \mathrm{yr}^{-1}$ in some areas of the tropical rain forest (Fig. 1). At one station in the mountains of Cameroon (Debundscha), mean annual rainfall exceeds $10000 \mathrm{~mm} \mathrm{yr}^{-1}$. Most of the continent is subhumid, however, and experiences a prolonged dry season or seasons during the course of the year. In the driest regions, the rainy season can be as short as 1 or 2 mo.

Traditionally, rainfall in all but the extra-tropical margins of the continent has been associated with the seasonal excursion of the Intertropical Convergence Zone (ITCZ). However, this is a very incomplete picture. The seasonal development of the tropical rain belt over Africa is driven by several features of the general atmospheric circulation, which in turn control the location and character of the ITCZ. In the lower atmosphere, these features include the high and low pressure cells and a shallow belt of equatorial westerlies. All of these features influence the interannual variability of climate.

\section{CLIMATIC CHANGE IN AFRICA}

\subsection{Availability of instrumental records and other climate-related information}

The meteorological record for Africa is of relatively short duration. Except for the countries of South Africa and Algeria, the temperate extremes of the continent, few instrumental records exist prior to the 20th century. The largest body of observations is for rainfall. Temperature records are available for a much smaller number of stations. These records are also shorter than those for rainfall and have not been extensively exploited.

Fig. 2 shows rainfall stations operating in select years: 1885, 1895, 1915, 1925, 1955 and 1985. Those for the first 2 years represent nearly all available records 
(Nicholson 2000b). In 1885, records were made at nearly 150 stations, but most were in coastal locations and/or confined to the countries of South Africa, Tunisia, or Algeria. A surge of interest in Africa greatly increased the station networks in the German, French and British colonies in the 1890s. A few records became available from Portuguese and Belgian colonies as well.

The rainfall station maps for the other 4 years show only the stations available in the various research archives in widespread use, i.e., the archive produced by Nicholson (1993) and the gridded African data sets of Hulme (1992) and Legates \& Willmott (1990) produced largely from that archive. This is only a subset of the available records, but the maps serve to illustrate changing station availability during the 20th century. For the continent as a whole, the most extensive records were available in the 1950s and 1960s. After that time, large numbers of stations opened up in some countries, but in numerous countries (e.g., Angola, Mozambique, Zaire, Uganda, Chad) the station networks greatly declined as a result of political instabilities and economic woes.

Despite this relative dearth of quantitative records prior to 1900, adequate historical information is available to put together a reliable picture of African rainfall variability throughout the 19th century (Nicholson 1978, 1980, 1981, 1996). This proxy material, dealing with such phenomena as droughts, floods, and harvests, and various hydrological indicators, has been compiled into a detailed semi-quantitative archive and combined with the available instrumental records to provide a quasi-continuous record for numerous regions since the early 19th century (Nicholson 2000a).

In this section, the historical trends are summarized. Then, rainfall variability during the 20th century is treated in detail. Finally, the 2 centuries are considered as a whole, using the semi-quantitative data set that combines the historical and instrumental record. A water balance model, applied to lake level variations, is used to make a rough quantitative comparison of major periods of variability during the 2 centuries.

\subsection{Historical variations in climate}

Climatic and environmental conditions that prevailed over Africa long ago were quite unlike those of today. Toward the end of the last Ice Age, ca $18000 \mathrm{yr}$ ago, the deserts expanded to cover most of the continent and humid climates were confined to a few highland areas. The continent became much more humid as the Ice Age ended about 10000 to $12000 \mathrm{yr}$ ago. By 5000 yr before present, the desert had nearly van-

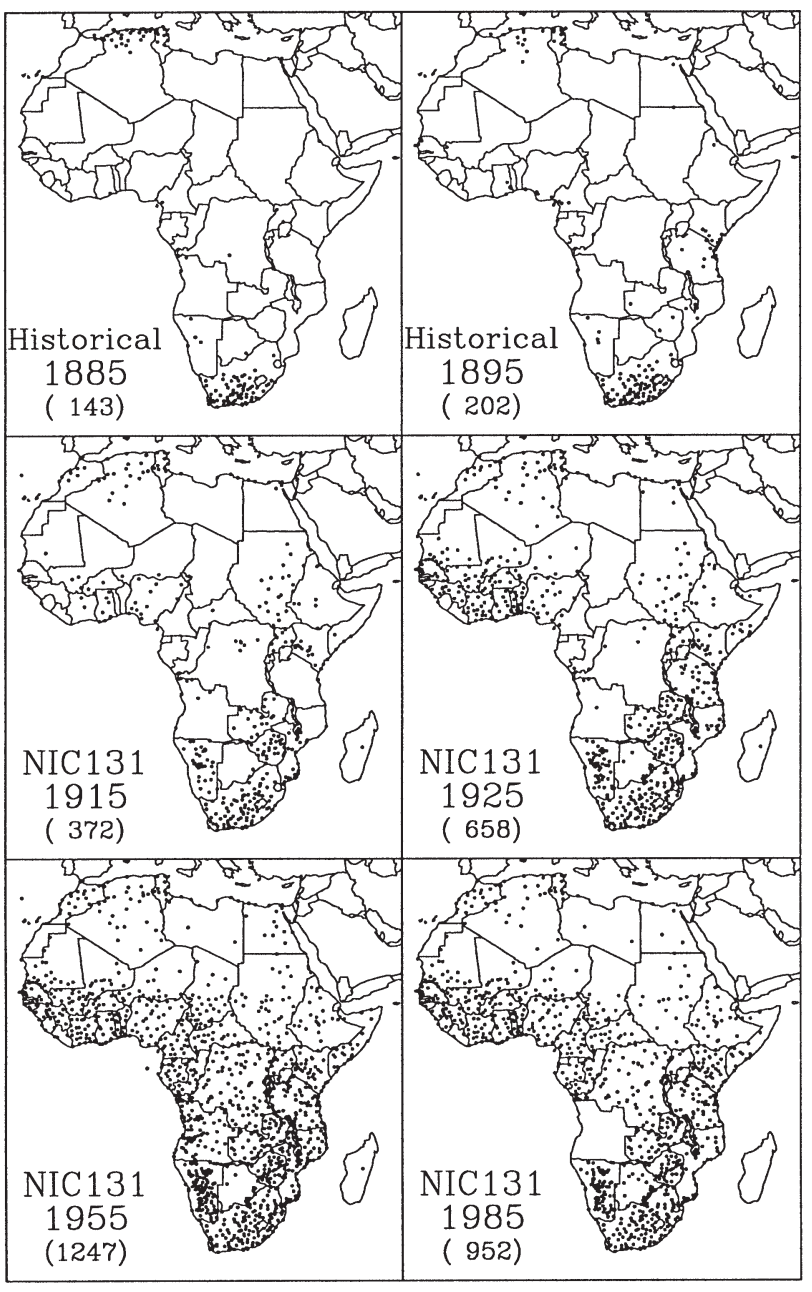

Fig. 2. Rainfall stations in the years $1885,1895,1915,1925$ 1955 and 1985. The stations in the maps of the last 4 years are those available in the archive of Nicholson (1993) and only represent a subset of total station availability, but illustrate the temporal trends in the station network

ished-marshes occupied the western Sahara, while Neolithic man herded cattle in what is now the central desert, surrounded by herds of antelope and other animals. Lakes dotted the Sahara; occasionally fish hooks are unearthed near what had been their shores. Lakes of the Rift Valley were several hundred feet deeper than at present; Lake Chad had grown to 10 times its modern size.

Evidence suggests that in the critical Sahel region, semi-arid climates set in about 2000 yr ago (Lézine 1989). Since that time, the climate in Africa as a whole has been generally similar to that of today, but significantly more arid and more humid periods have occurred (Nicholson 1980). One such humid period occurred in northern Africa from about the 9th through 14th centuries, the time of the Middle Ages in Europe. 


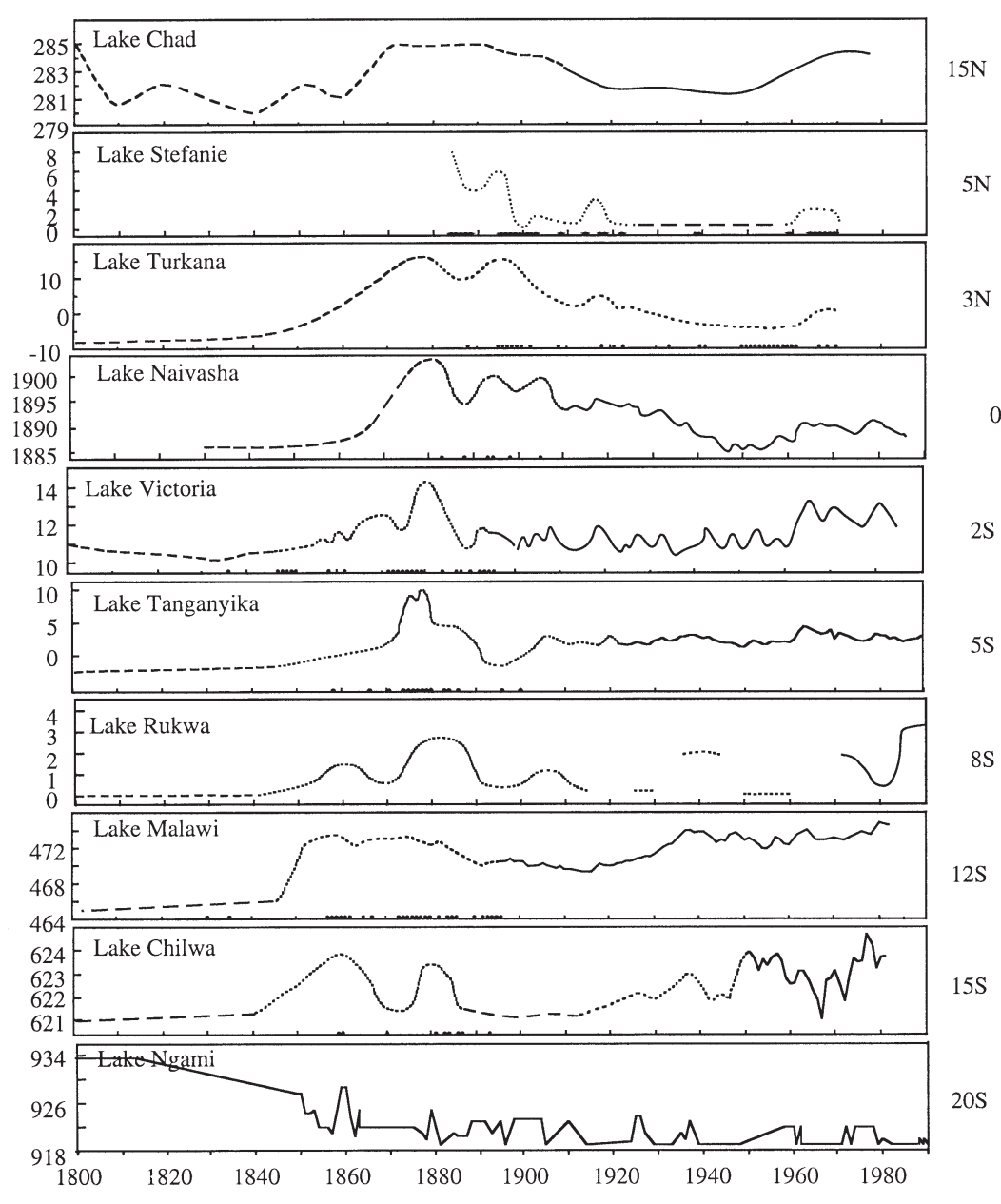

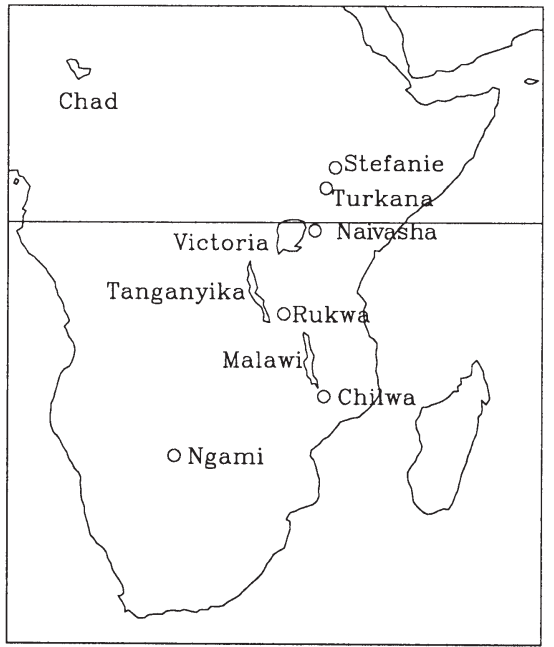

Fig. 3. Historical fluctuations of African lakes (from Nicholson \& Yin 2000). Except for Lake Ngami, solid lines indicate modern measurements, short dashed lines indicate historical information, and long dashed lines indicate general trends. Where indicated, the dots on the $x$-axis represent years with actual historical references. The lakes are shown on the location map; the horizontal line represents the equator
Elephants and giraffe roamed and caravans traversed what is now waterless desert; towns flourished in parts of the Sahara which are now too dry to support human occupation. Major civilizations, such as the Mali empire, thrived along the Sahara's southern margin in the present day Sahel.

Reports of settlers and travellers, local histories and geologic studies of lakes and rivers suggest that in the Sahel relatively humid conditions also prevailed from the 16th through 18th centuries. Details concerning that time period are summarized in Nicholson (1996). In the latter half of the period, this was probably true for other parts of Africa as well. In southern Africa, rushy grasses, swamps, springs, periodical rivers, and savanna animals occupied now dry regions. Lake Ngami in the Kalahari, now completely dry, was deep enough to produce powerful waves that washed hippos and fish to shore. At the end of the 18th century, more arid conditions rapidly set in and persisted through the first decades of the 19th century, but relatively wet conditions again returned in the latter half of the century.
The trends of the 19th century are illustrated by the temporal fluctuations of lakes spanning the latitudes $15^{\circ} \mathrm{N}$ to $20^{\circ} \mathrm{S}$ (Fig. 3). Further detail concerning these trends are presented in Nicholson (1998a,b, 1999). During the 1820s and 1830s, abnormally dry conditions affected most of Africa. Lakes, swamps, wells and rivers dried up; well-watered plains turned barren; farmers and tribesmen alike complained of continually decreasing rainfall; and in many regions extreme drought prevailed much of the time. The flow of the Nile was very weak and Lake Chad dried up, something which would not occur again until about the 1980s. By mid-century, most of the lakes had recovered and by the end of the 19th century, most had achieved very high stands, often exceeding any levels reached during the 20th century. Relatively wet conditions at end of the 19th century are evidenced by other indicators as well. In semi-arid West Africa, there were continually good harvests and high floods of the Niger River. Woodlands expanded into the Saharan margins and lakes and wells were common in this region. In the now semi-desert region of Tombouctoo, which 
depends on Niger floodwaters for agriculture, wheat was grown and even exported to surrounding countries.

Another change occurred around 1895, commensurate with a decline in rainfall in the global tropics (Kraus 1955). Thus, the 20th century commenced with a period of aridity similar to that $100 \mathrm{yr}$ earlier, although probably much less extreme. This culminated in severe and widespread droughts primarily in the 1910s and there was general concern about the desiccation of Africa. A drought commission was set up to study the problem in southern Africa and to evaluate the recommendation of a hydrologist, Schwarz (1920), that the Kalahari should be inundated in an attempt to bring back good rainfall to the region. As with the changes of the 19th century, the anomaly was relatively short-lived and 'good' rains returned within a decade. These more recent conditions are described in the following section.

\subsection{Rainfall variability during the 20 th century}

The most comprehensive studies of African rainfall variability during the 20th century are those of Nicholson (1993, 1994), Nicholson et al. (2000) and Hulme (1992, 1996). Fig. 4 presents an update of an analysis in Nicholson (1994) and describes the precipitation trends for several regions of the continent. The locations of these regions are shown in Fig. 5. Because a small number of spatial modes of variability serves to describe a large proportion of the overall variance in rainfall, the 11 time series provide a good picture of rainfall variability over most of Africa.

The relatively dry conditions early in the 20th century are apparent in most of the time series in Fig. 4. The exceptions are equatorial East Africa and the temperate extremes of the North and South 'Coasts' of Africa (Fig. 4a,b). In West Africa (Fig. 4c), relatively good conditions had returned during the 1920s and 1930s, but relatively dry conditions persisted in much of southern Africa. Generally drier conditions also characterized the North and South 'Coasts' and East Africa. In the 1940s, there was again widespread drought, particularly in West Africa.

More extreme fluctuations occurred in the latter half of the 20th century. These are evident in the time series in Fig. 4, but are accentuated with the continentalscale maps of the last 5 decades, presented in Figs 6 \& 7. The first period of note was the 1950s, when rainfall and river flow increased markedly in the semi-arid regions of both northern and southern Africa. For the continent as a whole, this was probably the wettest period since at least the 1870s and 1880s, but a pattern of sub-normal rainfall prevailed in the equatorial regions.
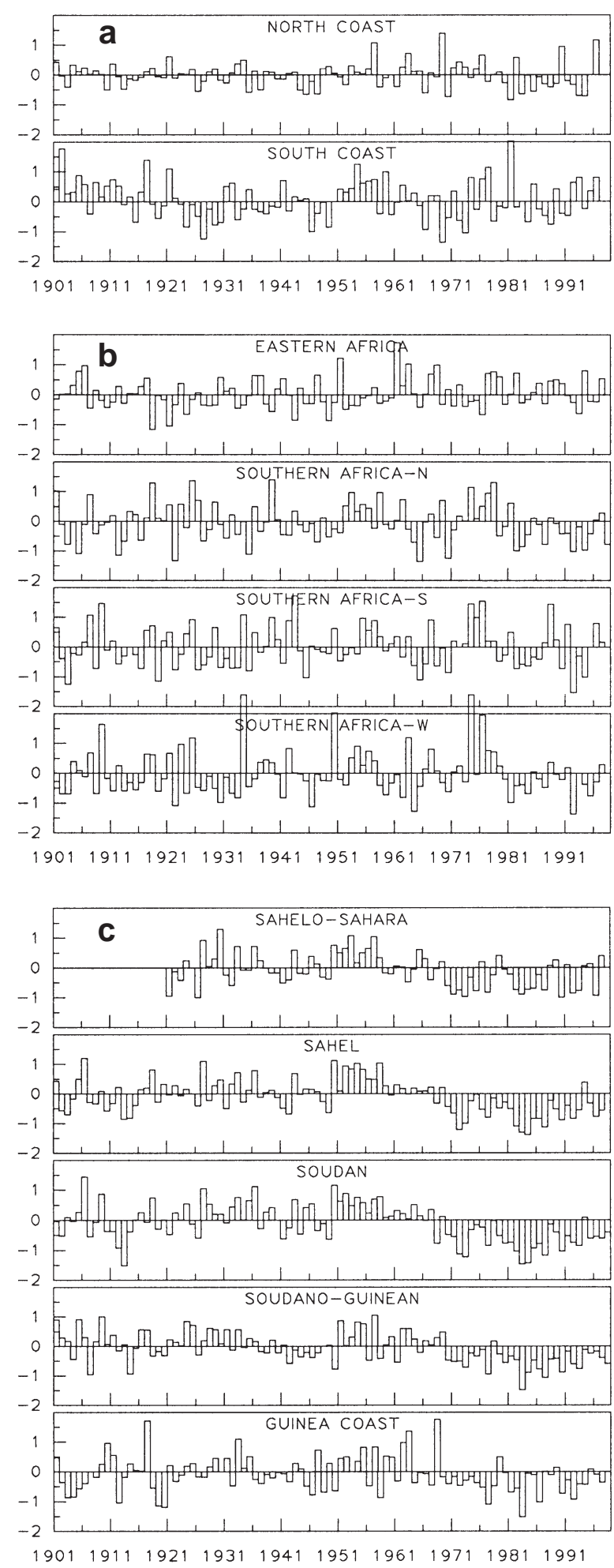

Fig. 4. Rainfall fluctuations 1901 to 1998, expressed as a regionally averaged standard deviation (departure from the long-term mean divided by the standard deviation). Locations of the regions are indicated in Fig. 5. (a) North African and South African littoral, (b) Equatorial and southern Africa, (c) West Africa 


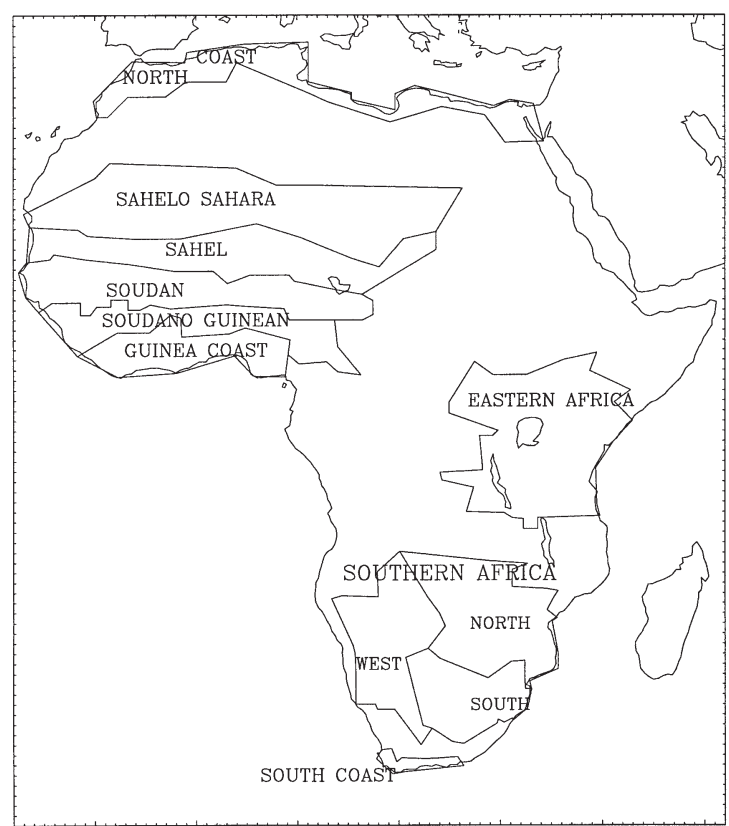

Fig. 5. Geographical regions represented by rainfall time series in Fig. 4

In the early 1960s another dramatic shift occurred, when rainfall increased dramatically throughout most of the equatorial region. The change was marked by an abrupt increase in the level of Rift Valley lakes, such as Victoria (Farquharson \& Sutcliffe 1998, Nicholson \& Yin 2000). The spatial pattern for the 1960s was roughly the inverse of that for the 1950s: lower rainfall in the subtropical latitudes, reduced rainfall in the low latitudes. By the 1970s, increased aridity was widespread, especially in the early 1970s (Nicholson 1994), but the decade as a whole was relatively wet in much of southern Africa, a result of several years of extremely high rainfall in mid-decade. By the 1980s, rainfall was below the long-term mean over most of Africa, a trend that has continued into the 1990s (Fig. 7).

Fig. 8 quantifies the magnitude of the changes that have taken place (see Nicholson et al. 2000). A comparison is made between the relatively wet period 1931-60 (long considered a climatological 'normal') and the period 1968-97, which coincides with the long period of aridity beginning in the late 1960s. The difference between the means for these periods is as much as 20 to $40 \%$ in Sahelian West Africa and on the order of 5 to $10 \%$ over much of the rest of the continent. In widespread areas of the Sahel, this change is equivalent to $0.4 \mathrm{~mm} \mathrm{~d}^{-1}$ (Hulme 1996). This is equivalent to a ca $1^{\circ}$ latitude shift in the rainfall isohyets over West Africa from June through August (Nicholson et al. 1998) (see Fig. 9). In many areas of equatorial Africa (e.g., the Guinea Coast and western equatorial region), rainfall increased by over $0.4 \mathrm{~mm} \mathrm{~d}^{-1}$ in these same months.

The magnitude of the rainfall anomalies for the 1970s and 1980s is indicated in Table 1, which expresses regionally averaged rainfall as a percent departure from the long-term mean and as a percent standard deviation (SD). In the arid regions of West Africa, rainfall was about half a SD below the longterm mean in the $1970 \mathrm{~s}$, but approximately 0.8 SDs in the 1980s. The change in the more humid Guinean regions was more moderate but was also greater in the 1980s. In East Africa, the averages for the 2 decades were 0.04 and 0.15 SDs above normal, respectively. In southern Africa, the increase in the 1970s, up to $0.56 \mathrm{SDs}$, was roughly equivalent to the decrease in rainfall in the $1980 \mathrm{~s}$. There, rainfall was only about 0.21 to 0.27 SDs below the long-term mean during the 1980s, thus the change was considerably smaller than in the Sahel. But the prevailing fact is that rainfall was below normal throughout most of Africa during the 1980s, and this pattern has generally prevailed through the 1990s.

\subsection{Two centuries of rainfall variability}

Fig. 10 shows semi-quantitative time series of rainfall since 1840 for 4 of the regions shown in Fig. 4. These are produced by combining proxy indicators of rainfall with the available instrumental records for the 19th century and from instrumental records for the 20th century. The details of the methodology are given in Nicholson (2000b). Data are assigned to 1 of 7 anomaly classes, with values ranging from -3 (driest) to +3 (wettest) and with 0 being indicative of 'normal' conditions.

This figure serves to provide some continuity over the last century and a half. Although only an approxi-

Table 1. Rainfall anomalies for the decades 1970-79 and 1980-89, expressed as a percent departure from the longterm mean and as a standardized departure (ratio of the departure from mean to the standard departure)

\begin{tabular}{|lrrrr|}
\hline & \multicolumn{2}{c}{$1970-79$} & \multicolumn{2}{c|}{$1980-89$} \\
& $\%$ & $\% \sigma$ & $\%$ & $\% \sigma$ \\
\hline Sahelo-Sahara & -31 & -47 & -24 & -35 \\
Sahel & -22 & -55 & -31 & -82 \\
Soudan & -13 & -53 & -20 & -85 \\
Soudano-Guinean Zone & -5 & -36 & -8 & -56 \\
Guinea Coast & -6 & -31 & -7 & -35 \\
Eastern Africa & 0 & 4 & 2 & 15 \\
Southern Africa-North & 6 & 20 & -5 & -21 \\
Southern Africa-South & 10 & 34 & -7 & -27 \\
Southern Africa-West & 26 & 56 & -12 & -25 \\
\hline
\end{tabular}



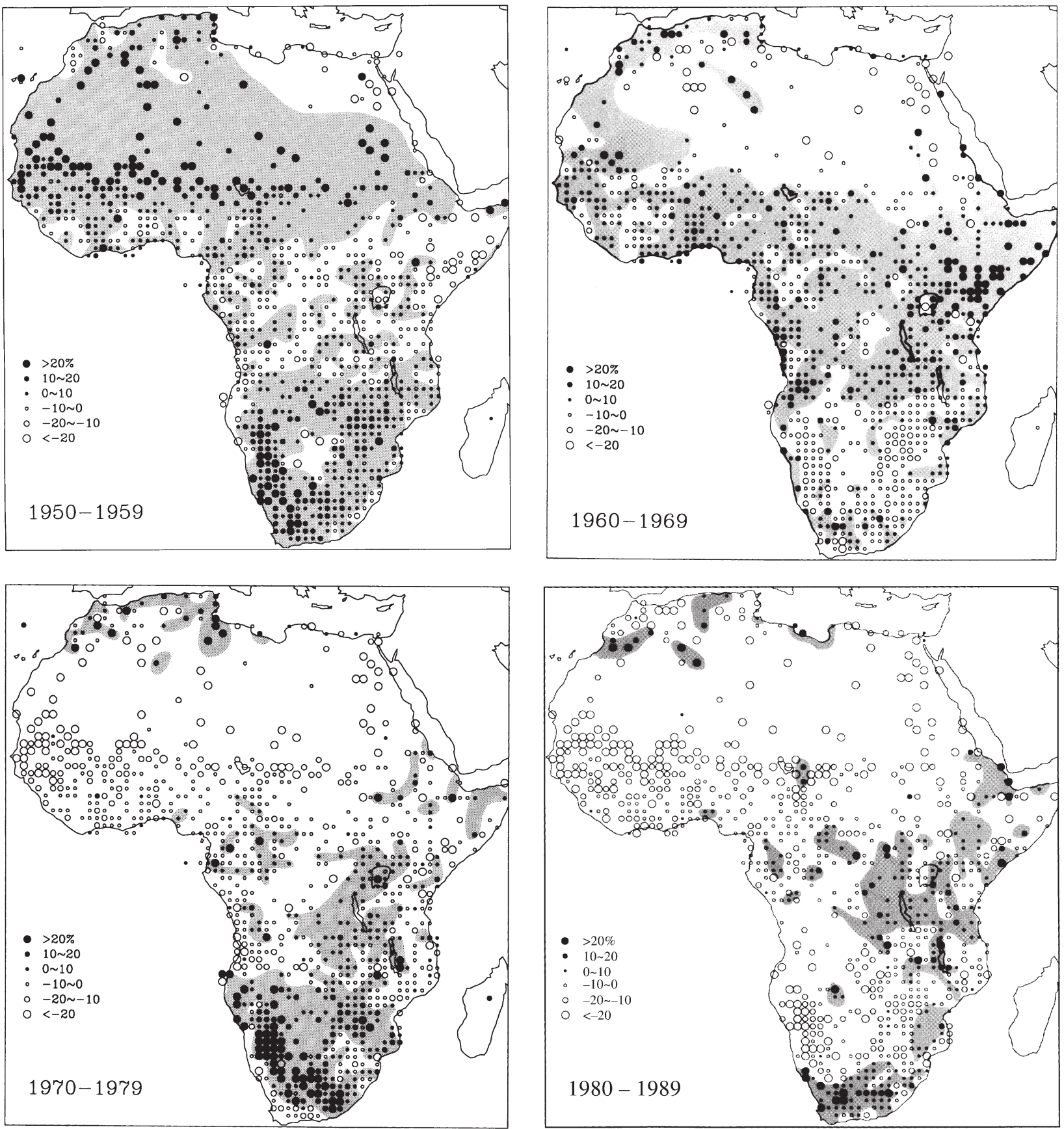

Fig. 6. Mean rainfall for the decades 1950-59, 1960-69, 1970-79 and 1980-89 (from Nicholson 1993). Rainfall is expressed as a percent departure from the long-term mean, with station data averaged over $1^{\circ}$ squares; positive values are shaded. These are based on the station network shown in Fig. 2

mate magnitude is indicated, the data clearly show extended periods of anomalous rainfall during the 19th century. Dry conditions were frequent during the 1840 s, 1850s and early 1860s in all 4 regions, analogous to the 1980 s decade. This was a continuation of even drier conditions that occurred during the first few decades of the century (Fig. 3). In the last 3 to 4 decades, rainfall was predominantly above average in all regions but East Africa, a pattern quite similar to the 1950s. Thus, the anomalous periods described in Fig. 6 for the 20th century are not unprecedented.

Although Fig. 10 provides only rough information on the magnitude of the changes, other information concerning the 19th century is more quantitative. For 


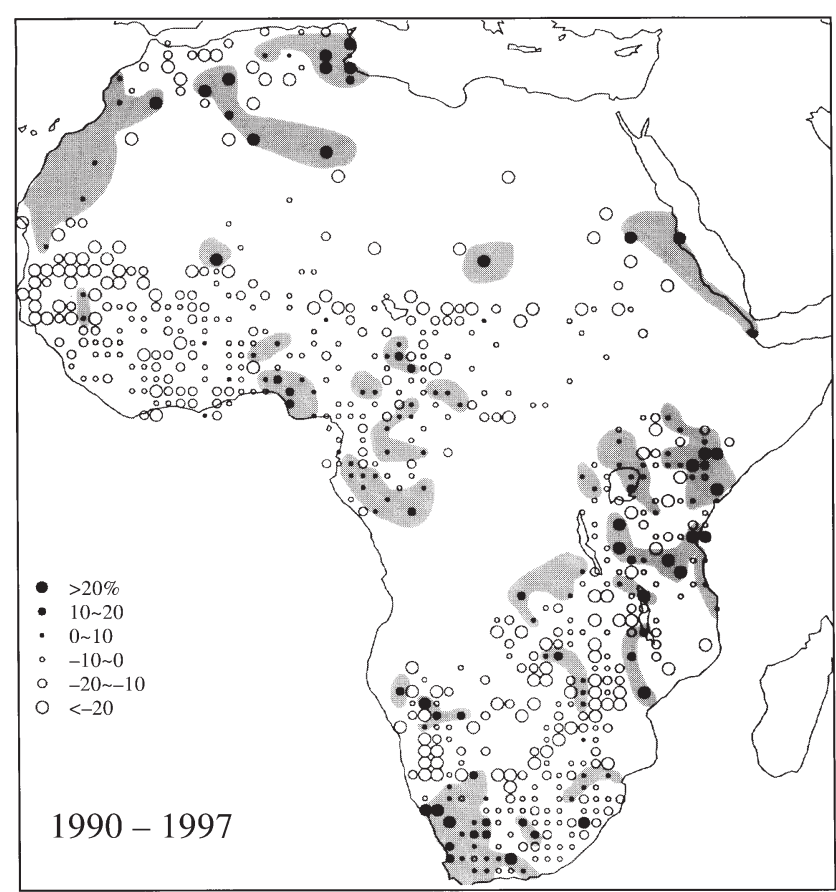

Fig. 7. Mean rainfall for the 8 yr period 1990-97 (from Nicholson et al. 2000). Rainfall is expressed as a percent departure from the long-term mean, with station data averaged over $1^{\circ}$ squares; positive values are shaded

example, Grove (1972) showed that the Nile discharge during the period ca $1880-95$ was about $35 \%$ greater than for the period 1910-40. Rainfall at Freetown, Sierra Leone, declined by a comparable amount during the same period (Nicholson 1981). Shaw (1985) calculated that the 19th century high stands of Lake Ngami required that it receive about $11 \%$ of the Okavango's current total inflow, implying a rainfall increase of about the same order of magnitude.

Nicholson \& Yin (2000) also produced estimates of the magnitude of change in the equatorial region, based on the levels of Lake Victoria (Fig. 11). The apparent desiccation of Victoria and other lakes early in the century could have resulted from rainfall during the period 1785 to 1835 that was only $12 \%$ below the modern mean. This calculation assumes no change of cloudiness. With a small change in cloud cover increasing the incoming solar radiation, a smaller change in rainfall would have been required to account for the lake level fluctuations. The high stands attained in the 1870s could similarly have been achieved with rainfall only $10 \%$ above the modern mean, but sustained for the period 1858 to 1878. Anomalies of this magnitude are not unusual today, but the result of sustained anomalies was relatively extreme changes in the physical environment of Africa.

\section{PROCESSES OF CHANGE}

Since the well-publicized drought of the 1960s and 1970s in the Sahel, numerous theories have been put forth to explain the occurrence of this drought and other climatic anomalies throughout Africa. Some of these have been strictly meteorological and/or linked to the global oceans; others have emphasized feedback processes associated with land surface changes that may have been coupled with the meteorological changes or independently produced through human activities. In this section, some of the most popular ideas are summarized and evaluated.

Clearly, there are common factors that influence most of the continent. The rainfall anomaly patterns of individual years and of decades tend to be continental in scale (Fig. 6). Recent work has shown, for example, that anomalously cold conditions over the Atlantic and Indian Ocean regions surrounding the continent tend to increase rainfall over Africa as a whole, while anomalously warm conditions tend to reduce it (Nicholson 1997). However, there are extensive regional differences in the nature of rainfall variability and in the degree of control of regional- versus global-scale factors.

For this reason, our current understanding of the processes of change is summarized separately for West Africa and for the semi-arid regions of East and southern Africa. The temperate extremes, with predomi-

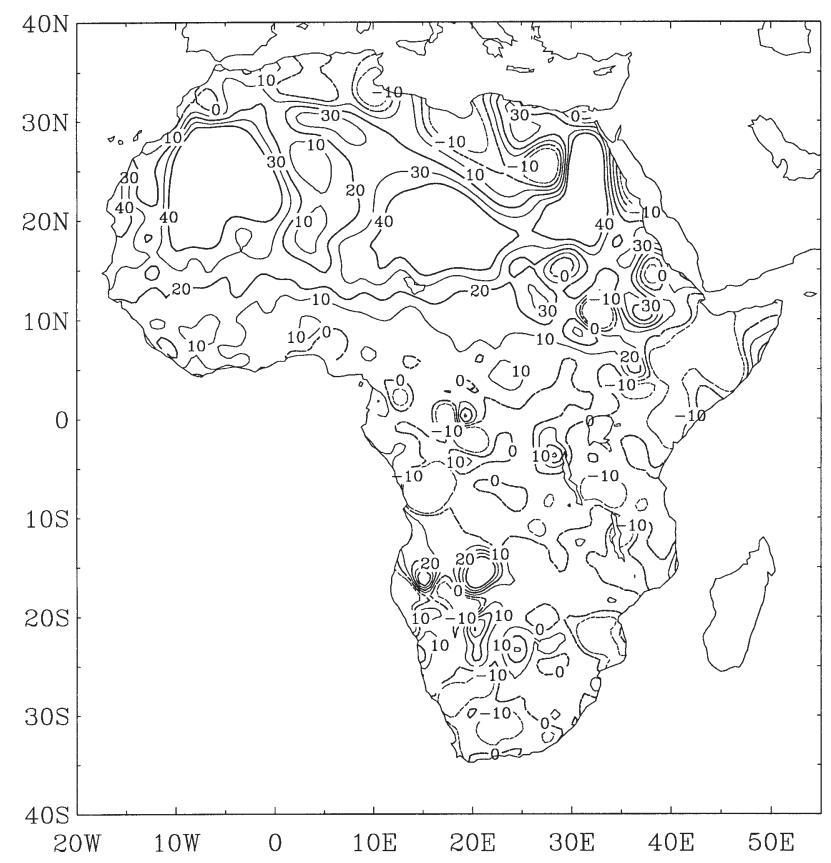

Fig. 8. Difference (in \%) between mean annual rainfall during 1931-60 and 1968-97 (from Nicholson et al. 2000) 


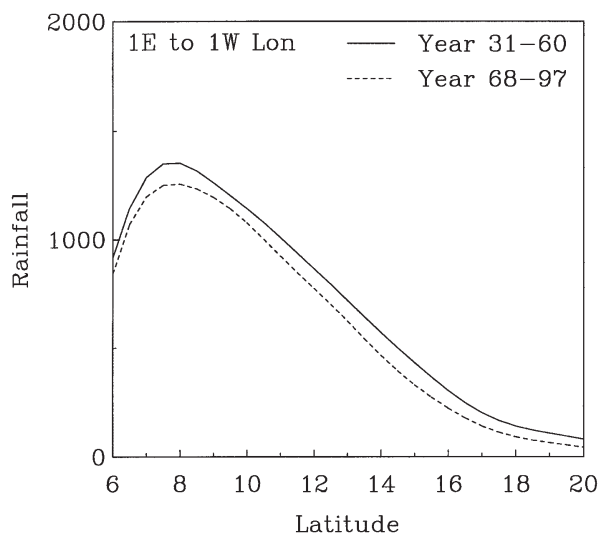

Fig. 9. Mean annual rainfall $(\mathrm{mm})$ as a function of latitude at $0^{\circ} \mathrm{W}$ for the periods 1931-60 and 1968-97 (from Nicholson et al. 2000)

nantly cold-season rainfall, are not considered, as rainfall there responds mostly to mid-latitude changes that are described in more detail elsewhere (e.g., Bradley et al. 1987). Likewise, the central equatorial region is not considered, as the meteorological processes governing variability there are not well understood.

There are several reasons for a separate discussion of processes over West Africa. For one, the nature of rainfall variability is quite different there. In the Sahel-Soudan region of West Africa, much of the variance is concentrated on decadal time scales and there is a strong year-to-year persistence of anomalous conditions over much of the region. This implies a somewhat different set of controls on this region compared to others, where global-scale phenomena such as the El Niño/Southern Oscillation (ENSO) have a dominant influence. Also, the meteorological aspects of rainfall variability have been much more intensively studied over West Africa. Finally, there is a considerable body of knowledge that suggests that feedback between the land and atmosphere may play a significant role in the semi-arid regions of West Africa. These feedback processes are treated in Section 4.2 .

\subsection{Atmospheric and oceanic processes}

\subsubsection{West Africa}

Over the last $20 \mathrm{yr}$ our understanding of the factors which govern the interannual variability of rainfall in West Africa has increased substantially. The earliest hypotheses concerning the cause of the Sahel drought were largely confined to the latitudinal displacement

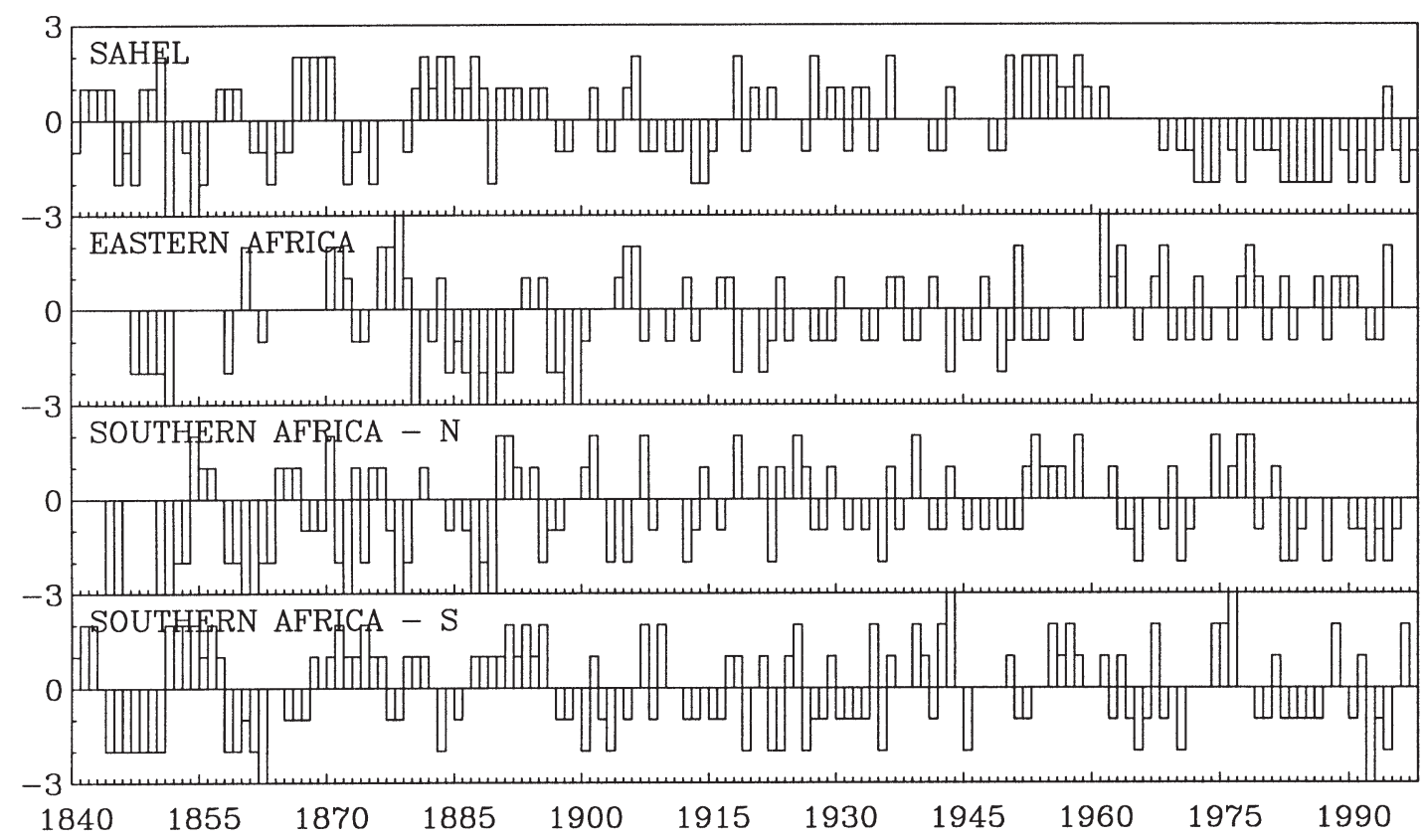

Fig. 10. Rainfall variability in 4 African regions (see Fig. 5 for location), 1840-1997. Rainfall is described via a semi-quantitative index ranging from -3 (extremely dry conditions) to +3 (extremely wet conditions) (from Nicholson $2000 \mathrm{~b}$ ). The classes of \pm 1 indicate mildly wet or dry. The \pm 2 classes indicate more severe conditions, with some human consequences in the case of proxy data (e.g., food shortages induced by drought or destructive flooding). The most extreme category is reserved for events described in superlative terms. For instrumental data, the category is based on the annual rainfall departure, with $\pm<0.25$ SDs defining the 'normal' or 0 category and \pm 0.75 and 1.5 SDs defining the second and third categories, respectively 


\section{Lake Victoria}

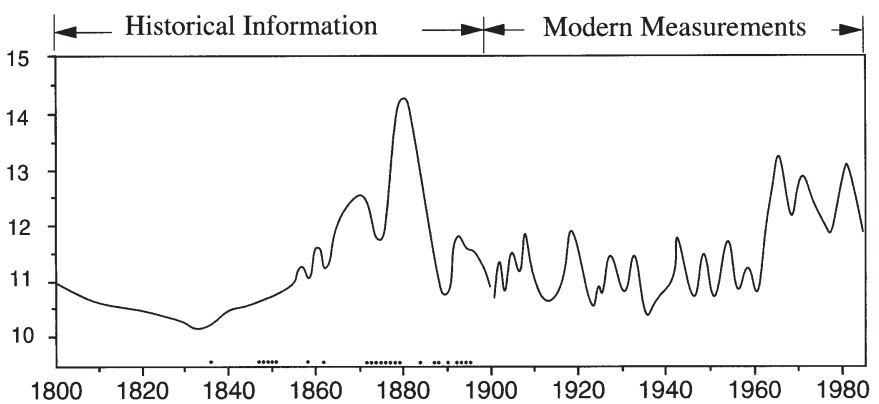

Fig. 11. Fluctuations of Lake Victoria since 1780. Years for which specific references are available are indicated at the bottom with dots. Levels since 1896 are based on modern measurements and earlier years are reconstructed from historical references. Dashed line indicates period for which only general trends, not data for specific years, can be ascertained

of the ITCZ, often in response to latitudinal shifts in the mid-latitude pressure zones. The current picture is one in which large-scale changes of sea-surface temperature (SST) patterns promote changes in several major atmospheric circulations that influence West Africa (Lamb 1978, Hastenrath 1990, Folland et al. 1991, Lamb \& Peppler 1992, Wagner \& da Silva 1994, Ward 1998). Notable among these is the African Easterly Jet $(\mathrm{AEJ})$, a feature that helps to generate and maintain the wave disturbances that modulate the rainfall field in the region.
In general, the 'wet' years in the Sahel tend to be characterized by a pattern of SSTs in which the tropical Atlantic is anomalously warm, compared to dry years, while anomalously cold SSTs prevail to the west of the continent. In the dry years, the AEJ is generally stronger than in the wet years and is displaced equatorward, while the Tropical Easterly Jet is unusually weak. The ITCZ is often likewise displaced further south and/or abnormally weak. Important changes have also been noted in atmospheric moisture flux and divergence fields over the continent and in the nature of the convective disturbances affecting the region.

The issues that are least understood are the direct relationships between the characteristic changes over the ocean and those in the circulation features over the continent, the relationship between the wave activity associated with the jet and the convective disturbances that bring most of the region's rainfall, and the influence of the ENSO on rainfall over West Africa. The ENSO phenomenon has been shown to have a decisive influence on rainfall in some regions, most notably the Guinea Coast, where it tends to enhance rainfall. Its influence in the Sahel has been disputed, with some studies noting a tendency for the ENSO to be associated with reduced rainfall and others concluding that there is little consistent influence in the region. The most notable study is that of Ward (1998), which suggests that its influence is primarily on higher frequency fluctuations (i.e., on individual years rather than the decadal-scale wet and dry intervals). Ward (1998) also a

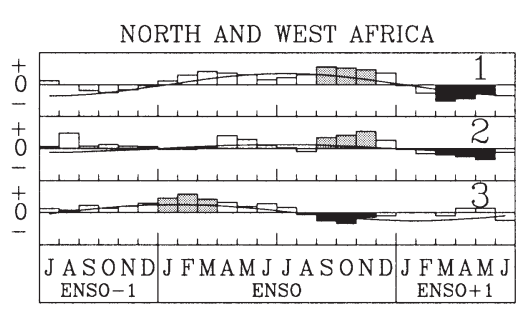

C EQUATORIAL AND SOUTHERN AFRICA

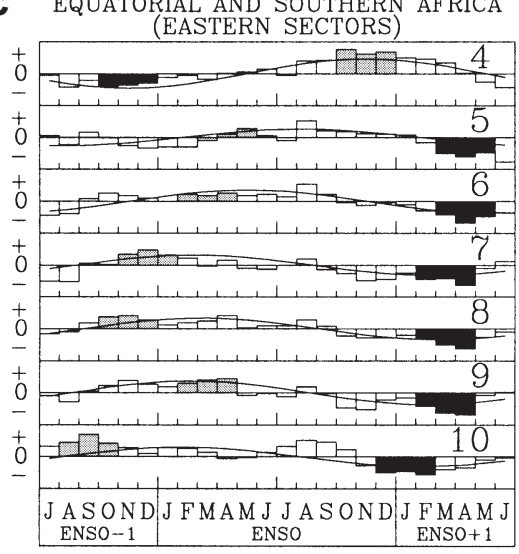

b

EQUATORIAL AND SOUTHERN AFRICA
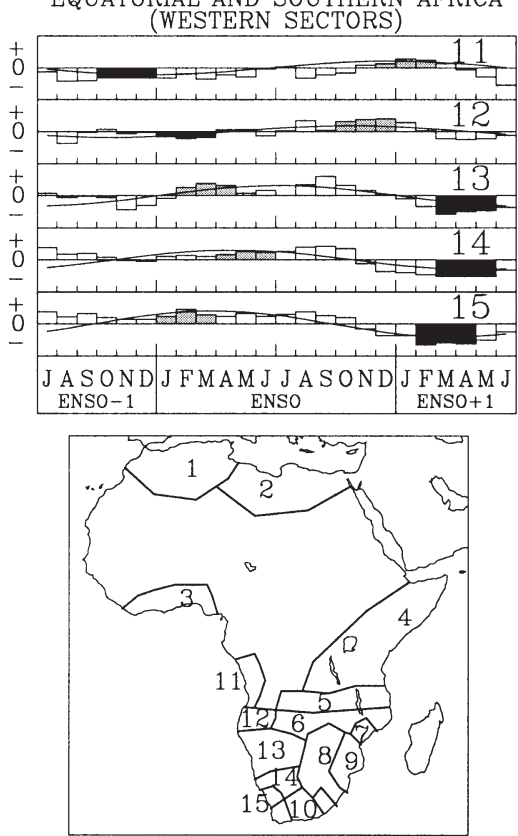

Fig. 12. ENSO-composite rainfall anomalies for 15 African sectors (see map for locations) (from Nicholson \& Kim 1997). Time series commence in July in the year prior to the ENSO and continue to June of the year following it. Shadings indicate 'seasons' of possible ENSO-related rainfall response, with dark shading indicating seasons of maximum negative rainfall anomalies and light shading indicating seasons of maximum positive rainfall anomalies. Amplitude is an index based on rank. (a) North and West African sectors; (b) western sectors of equatorial and southern Africa; (c) eastern sectors of equatorial and southern Africa 
Fig. 13. La Niña-composite rainfall anomalies for 6 African sectors (see map for location) (from Nicholson \& Selato 2000). Time series commence in July in the year prior to La Niña and continue to June of the year following it. Shadings indicate 'seasons' of possible La Niñarelated rainfall response. Amplitude is an index based on rank. (a) North and West African sectors; (b) western sectors of equatorial and southern Africa; (c) eastern sectors of equatorial and southern Africa

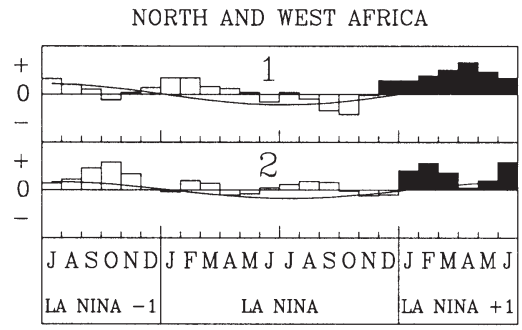

b EQUATORIAL AND SOUTHERN AFRICA (EASTERN SECTORS)

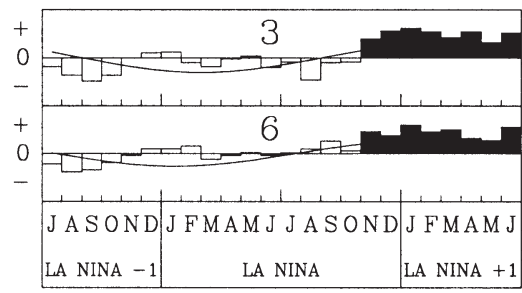

C

EQUATORIAL AND SOUTHERN AFRICA (WESTERN SECTORS)
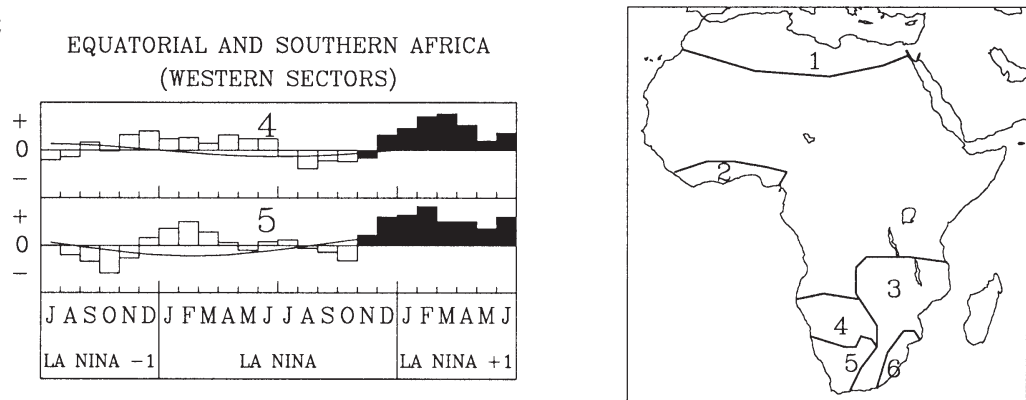

notes that the influence of the ENSO appears to be greater during relatively dry intervals than during relatively wet ones, suggesting greater coupling of the region to global atmospheric processes during a 'dry' mode.

\subsubsection{Eastern and southern Africa}

Eastern and southern Africa are regions of mainly semi-arid and subhumid climates with a pronounced dry season during at least part of the year. In contrast to West Africa, the variability of rainfall is concentrated on relatively short time scales. The primary ones are roughly 2.3, 3.5 and $5 \mathrm{yr}$, the same time scales that dominate the ENSO phenomenon and global SST variability (Nicholson 1989). This suggests a direct connection between rainfall variability in these regions and global processes.

Throughout these regions, there is a strong ENSO signal in rainfall variability (Fig. 12). Rainfall tends to be enhanced in East Africa toward the end of the ENSO year and early in the following year. It tends to be reduced in southern Africa at this same time, particularly in the months of February through May of the year following the ENSO. The opposite pattern tends to prevail, but less consistently so, in the year preceding the ENSO and in the cold La Niña (Fig. 13).

An examination of SST patterns during these events shows a somewhat different picture. The anticipated ENSO signals materialize when a specific pattern of SSTs develops, in conjunction with the ENSO, in the
Atlantic and Indian Ocean regions surrounding Africa. Such patterns develop in roughly 3 of every 4 ENSO events (Nicholson 1997). Thus, the factor of primary importance is the SSTs in proximity to Africa, rather than the ENSO itself. In this context, specific regions may be particularly important. The eastern Atlantic and parts of the western Indian Ocean, for example, influence rainfall over much of equatorial and southern Africa (Nicholson \& Entekhabi 1986, Hastenrath et al. 1993, 1995, Mason et al. 1994, Mason 1995, Rocha \& Simmonds 1996).

\subsection{Land surface effects}

\subsubsection{General}

The highly populated West African Sahel has historically been prone to long and severe droughts. Commensurate with the drought of the 1960s and early 1970 s arose the idea that the region was also undergoing a long-term process of desertification, which may have exacerbated or even caused the drought and most certainly enhanced its impact. Charney's (1975) classic paper on the Sahel, for example, speculated that albedo changes related to overgrazing and denuding of the highly reflective soil may have contributed to, or even been responsible for, the drought. This section examines some of the key, related issues: the concept of desertification, long-term albedo changes, atmospheric dust loading, and general hydrologic feedbacks to the atmosphere. 


\subsubsection{Desertification}

Nearly 2 decades ago the United Nations (Biswas \& Biswas 1980) announced that desertification had affected some 35 million $\mathrm{km}^{2}$ of land globally and that overall $35 \%$ of the earth's land surface was at risk of undergoing similar changes. The official UN definition was 'diminution or destruction of the biological potential of the land [which] can lead ultimately to desertlike conditions.' The process was defined as humaninduced, with the role of climate being essentially one of producing susceptibility. However, the UN map of desertification status in Africa (Fig. 14) looked remarkably like a rainfall map. Other definitions of desertification abound (Graetz 1991), with most encapsulating the idea that desertification is 'the expansion of desertlike conditions and landscapes to areas where they should not occur climatically.' Recently, the UN changed its definition to 'land degradation in arid, semiarid and dry sub-humid areas resulting from various factors, including climate variations and human activities' (Puigdefabregas 1995, Warren 1996).

The original UN estimates were largely erroneous. The extent of affected lands was greatly exaggerated

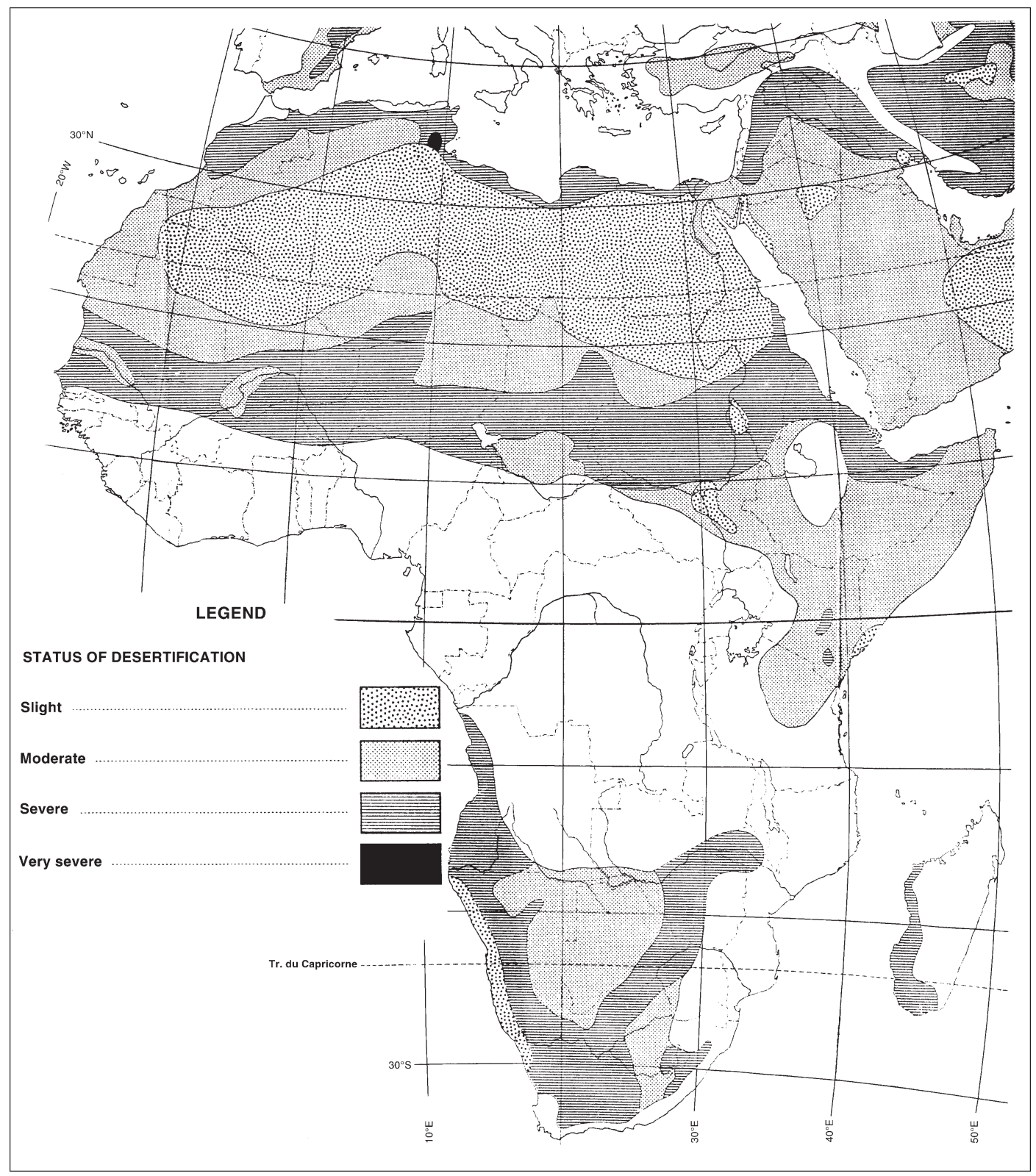

Fig. 14. United Nations (1980) map of the status of desertification over Africa 
and the issue of desertification has become a controversial one, suffering from a dearth of data and rigorous scientific study (see Verstraete 1986, Graetz 1991, Hellden 1991, Mainguet 1991, Thomas \& Middleton 1994). Desertification estimates for Africa, in particular, were problematic for 2 reasons (Nicholson et al. 1998). For one, the information was largely anecdotal. Secondly, the few actual assessments extended over periods of drought or rainfall decline. A prime example is the so-called 'advance of the desert' into the Sahel. This concept was based on 2 assessments of the geographical limits of the Acacia tree in the Sudan. Using maps from the 1950s and aerial surveys from 1975 for this assessment, Lamprey (1975) concluded that between 1958 to 1975 the desert had advanced southward in the western Sudan by 90 to $100 \mathrm{~km}$. During this same period, rainfall in the Sahel declined by nearly $50 \%$, with a somewhat lesser reduction in the western Sudan (Nicholson 1990). Thus, while desertification itself was defined as anthropogenic, the evidence used to assess it could equally have been a product of climatic variability. This is true of many other instances of supposed widespread desertification in areas of the United States, Australia and elsewhere (Nicholson et al. 1998).

Equally problematic is the perception that has developed of the process of desertification. The term evokes an image of the 'advancing desert', a living environment becoming irreversibly sterile and barren. This paradigm is used in climatic studies of desertification (e.g., Charney et al. 1975, Xue \& Shukla 1993, Dirmeyer \& Shukla 1996), which essentially strip land of its vegetation cover and assess the impact. However, it has long been recognized that the process has a much different character. Studies in the Sudan by various scientists at the University of Lund (Hellden 1984, Olsson 1985, Ahlcrona 1988) showed through a combination of field work and analysis of satellite photos that there was neither a systematic advance of the desert or other vegetation zones, nor a reduction in vegetation cover, although degradation and replacement of forage with woody species was apparent. There was no evidence of a systematic spread of desertified land around villages and waterholes or of reduced crop yield due to cultivation of marginal or vulnerable areas. On the other hand, these studies clearly demonstrated that changes took place in response to drought, with full recovery of the land productivity at the end of the drought. Tucker et al. (1991), Nicholson et al. (1998) and Tucker \& Nicholson (1998) reached a similar conclusion for the Sahel as a whole. The 'advances' of the desert during recent years closely mimic the fluctuations of rainfall in the Sahelian region (Fig. 15), and there has been no large-scale reduction in biological productivity in the region (Prince et al. 1998).

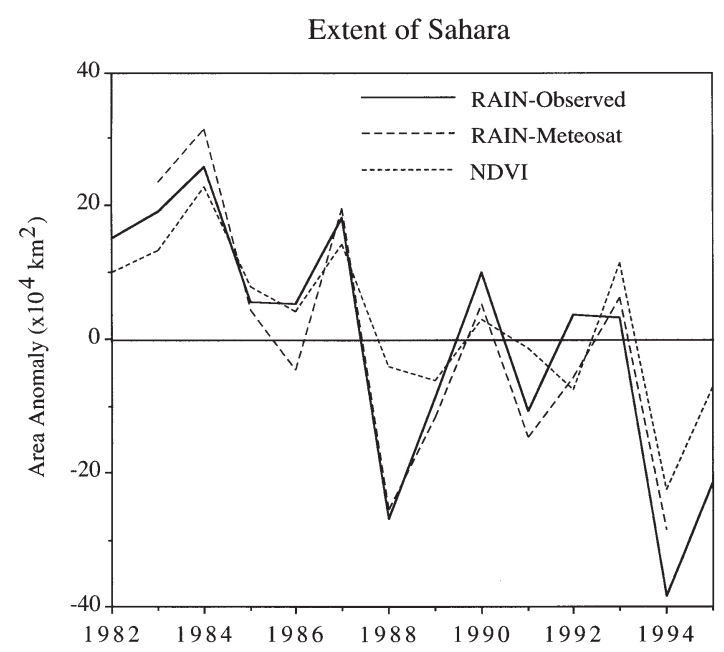

Fig. 15. Extent of the Sahara desert, calculated as the area between the $200 \mathrm{~mm}$ isohyet and $25^{\circ} \mathrm{N}$ : solid line-as assessed from rainfall stations; dashed line - - - as assessed from Meteosat data; dotted line-as assessed from NDVI. Area in $104 \mathrm{~km}^{2}$ is calculated with respect to the mean area during the period 1980-95 (from Nicholson et al. 1998)

None the of above facts belies the idea that desertification is a problem. It is a process of land degradation with many biophysical components. The topsoil is eroded, adding to the atmospheric dust loading, and tracts of land are washed away to produce huge gullies. The soil's texture, organic matter and nutrient content are changed in ways that reduce its fertility. Poor irrigation and management practices lead to salinization and waterlogging of the soil. Although land cover may become more barren, it is more commonly the case that diverse and nutrient-rich species are replaced by vegetation of poorer quality.

This complexity is recognized in new assessments of desertification (e.g., Schlesinger et al. 1990, Middleton \& Thomas 1992, Warren 1996). However, further effort is needed to quantify the various processes of degradation (e.g., soil erosion, salinization, waterlogging, encroachment of undesirable species and dust generation) which comprise desertification. Additional information is also needed on the overall vegetation changes and land-use change, in order to better distinguish between between climatic impacts on the land and human ones.

\subsubsection{The albedo issue}

In an address to the Royal Meteorological Society, Charney (1975) suggested that desertification may have caused the Sahel drought to occur. His mechanism was based on the exposure of highly reflective 
soil as a result of overgrazing, a hypothesis also put forth by Otterman (1974). Using a simple dynamic model, Charney showed that such an increase in surface albedo would increase radiative losses over the Sahara, thereby enhancing the negative net radiation balance of the desert and adjacent Sahel. These results suggested a positive feedback mechanism by which droughts could be self-accelerating, or could perhaps even be produced. This paper was followed up by several general circulation model (GCM) experiments that drew conclusions consistent with Charney's original hypothesis (e.g., Charney et al. 1975, 1977, Sud \& Fennessy 1982, Sud \& Molod 1988, Xue \& Shukla 1993, Dirmeyer \& Shukla 1994, 1996, Lofgren 1995a,b).

The various model simulations are in general agreement that, if a very large change in surface albedo is induced in semi-arid regions such as the Sahel, a regionally significant decrease in rainfall should result. The question that has not been adequately addressed is the extent to which such albedo changes have taken place. Few measurements have been carried out, but 3 case studies are worth noting: a study of 'protected' and 'unprotected' grazing areas in Tunisia and studies that surveyed grazed and ungrazed sides of international borders in the Sinai/Negev and the Sonoran Desert of the US and Mexico. Satellite photos (Otterman 1977, 1981) indicate that the soil in the overgrazed Sinai has an albedo of 0.4 in the visible and 0.53 in the infrared; in the protected area of the Negev, the visible and infrared albedos were 0.12 and 0.24 respectively, but in most of the region the albedo averaged about 0.25 . In Tunisia the albedo of protected versus unprotected sites was 0.35 versus 0.39 in one case and 0.26 versus 0.36 in another, while oases had albedos on the order of 0.10 to 0.23 (Wendler \& Eaton 1983).

These changes are roughly of the same order of magnitude as the albedo changes in the Charney models. However, they are quite small in spatial scale. The few large-scale studies conducted over Africa have suggested a different picture. Early studies of Norton et al. (1979) and Courel et al. (1984) showed that in the southern Sahel, albedo progressively increased between 1967 (a 'normal' year) and 1973 (the worst drought year) by $\sim 20 \%$ during the dry season $(0.29$ to 0.34 ) and by $\sim 50 \%$ during the wet season ( 0.23 to 0.33 ). However from 1973 to 1979 , i.e., after the drought ended, albedo decreased by 20 to $60 \%$ in the Sahel. Thus, the change in albedo was neither permanent nor progressive and tended to follow the changing rainfall patterns, a conclusion drawn also by Olsson (1985) for areas of the Sudanese Sahel further east. Nicholson et al. (1998) added a few additional years of study to the albedo question, examining the extreme dry years 1983 and 1984, plus the wetter years 1985 to 1988. This study provided further evidence of the link between rainfall and surface albedo and the lack of a progressive increase in albedo. This study also found that the total year-to-year albedo variation during the analysis period was about half as great as the albedo change between the wet and dry seasons.

Unfortunately, all of the above estimates of surface albedo have been within a relatively dry period. An increase in albedo on a large scale between the sustained wetter interval in the Sahel during and prior to the 1950s and the subsequent 3 dry decades cannot be ruled out. However, there are clear constraints on the possible degree of change. Gornitz (1985) examined the potential effects of land-use change throughout West Africa over the course of the century and found that the documented changes would have had minimal influence on surface albedo. Ba et al. (2000) also demonstrated that the overall surface albedo is largely constrained by the overall character of the surface vegetation, including the presence or absence of boreal elements and their density. The overall vegetation character does not change on time scales of years, but there is considerable evidence that it has changed over time scales of decades in large parts of the Sahel (e.g., Akhtar-Schuster 1995). Ba et al. also showed that a decrease in vegetation density can actually decrease surface albedo, as the number of geometric elements reflecting the light is lower. This is the case in the woodlands.

Several conclusions can be made, based on these earlier studies. For one, no large-scale increase in surface albedo has been demonstrated over Africa, but a significant change in the relatively narrow Sahel zone since the 1950s is conceivable. In view of this possibility, the albedo issue merits further examination. Finally, the issue is a complex one and the assumed increase in surface albedo with reduced vegetation cover is not realistic. A better assessment requires more realistic consideration of the influence of vegetation on surface albedo and better documentation of long-term vegetation changes in the region.

\subsubsection{Dust}

There have been relatively few measurements of aerosols over Sahelian West Africa. Five studies (Oluwafemi 1979, ben Mohamed \& Frangi 1983, 1986, Fouquart et al. 1987a, Faizoun et al. 1994, Pinker et al. 1994) have used sun photometers to make measurements at a single station. Studies by Cerf (1980), Holben et al. (1991), d'Almeida (1986, 1987), ben Mohamed et al. (1992) and Faizoun et al. (1994) have some degree of spatial coverage, varying from 2 to 11 stations. In some cases, measurements are limited to a few months; many cover a 1 or 2 yr period at each station. 
All of these studies have demonstrated a high temporal and spatial variability of both optical thickness and aerosol properties, as well as a pronounced seasonal cycle. However, they are inadequate for examining long-term trends in dust over West Africa. Recently developed satellite methodologies will facilitate such long-term monitoring. A radiatively equivalent optical thickness can be obtained over ocean areas using NOAA AVHRR data (Husar et al. 1997). The TOMS instrument (Tropospheric Ozone Monitoring System) is also being utilized to provide estimates of optical thickness over land of scattering aerosols.

Fortunately, atmospheric visibility is related to dust concentration, and visibility data have been useful to examine the spatial and temporal distribution of dust in the region over multi-year periods ( $\mathrm{N}^{\prime}$ Tchayi Mbourou et al. 1994, 1997). The latter study examined the spatial distribution of dust by season throughout West Africa for the 3 periods 1957-61, 1970-74 and 1983-87 (Fig. 16) and long-term trends since 1957 at individual stations (e.g., Fig. 17). From these analyses, it is apparent that (1) there has been a steady increase in the frequency of occurrence of dust conditions at the surface over West Africa since the early 1970s, (2) that it has paralleled a downward trend in rainfall, and (3) that the length of the season with dusty conditions has continually increased. The implication of this study is that there has been a steady build-up of dust over West Africa since the early 1970s. This is confirmed by a consistent upward trend in African dust measured at sites downstream (Prospero \& Nees 1986).

West Africa is the source of nearly half of the mineral aerosols residing in the atmosphere (Andreae 1995, Duce 1995). Commonly termed 'Saharan dust' or 'desert dust', it was long assumed to originate in the Sahara. Recent evidence suggests instead that most of it originates in the semi-arid Sahel-Soudan region (e.g., Prospero \& Nees 1986, Prospero 1996, N'Tchayi Mbourou et al. 1997). This evidence includes the excellent inverse correlation (Fig. 18) between Sahel rainfall and dust transport across the tropical north Atlantic and the seasonal displacement of the 'Saharan' dust plume, moving some $10^{\circ}$ latitude southward in winter (Prospero \& Nees 1986, Prospero et al. 1993, Prospero 1996). Air mass trajectories and the composition of particles point to the Sahel as a source of dust outbreaks in the Canary Islands (Bergametti et al. 1989). Also, in North Africa and elsewhere the buildup of dust is better correlated with Sahelian rainfall than with local conditions (N'Tchayi Mbourou et al. 1997).

The impact of the dust build-up on meteorological processes over West Africa is not adequately known, but several recent studies suggest that its effect could be quite significant. GCM modelling studies have shown that regional climate cannot be realistically simulated without introducing the dust mobilization in the model. For example, Tegen \& Fung (1994), using the GISS GCM with an aerosol tracer and 'natural' conditions of soil and vegetation over West Africa, showed a seasonally invariant dust plume of Saharan origin. When the model allowed for 'disturbed' soils in the Sahel as a result of the long series of recent drought years and changes in land management practices, a more realistic, seasonally migrating plume resulted (Tegen \& Fung 1995). In fact, the study suggested that 'disturbed' sources resulting from climate variability, cultivation, deforestation and wind erosion contribute some 30 to $50 \%$ of the total atmospheric dust loading and associated radiative forcing.

Models of convection and wave development have shown that the dust has an impact on synoptic conditions and, therefore, presumably on rainfall as well. Using a mesoscale model and doing case study simulations of 2 dust outbreaks, Karyampudi \& Carlson (1988) concluded that the layer is important for the maintenance and possible growth of some wave disturbances and that it acts to strengthen the mid-level AEJ. Chang (1993) examined the effect of the dust indirectly by contrasting the influence of the thermal states of the atmosphere over the Sahara north of the AEJ (i.e., in the dust layer) and in the wetter region to the south of the jet. The thermal structure associated with the dust layer altered the stability mechanisms and energy conversion processes important in generating waves from the jet, and it also altered wave characteristics such as growth rate and wavelength.

The impact of African dust on atmospheric heating is quite complex because it modifies both the shortwave solar radiation transmitted through to the surface and the longwave infrared radiation emitted to space. It was long assumed that the African dust would have little impact on large-scale climate because of low light scattering efficiency and low concentrations. However, Li et al. (1996) have shown that, although the mass scattering efficiency of this mineral dust is only onequarter that of non-seasalt sulphate, its annual mean concentration over the North Atlantic its 16 times as great.

The dust both scatters and absorbs solar radiation, but the scattering effect dominates in the visible portion of the spectrum (Li et al. 1996, Tegen et al. 1996). Andreae (1996) suggests this would imply a net cooling effect in the visible portion of the spectrum, but Tegen et al. (1996) conclude that either a cooling or heating effect can occur, depending on cloud cover and on the albedo of the underlying surface. The African dust also absorbs shortwave radiation and absorbs and emits infrared radiation; hence its precise effect on the thermal structure of the atmosphere is not 

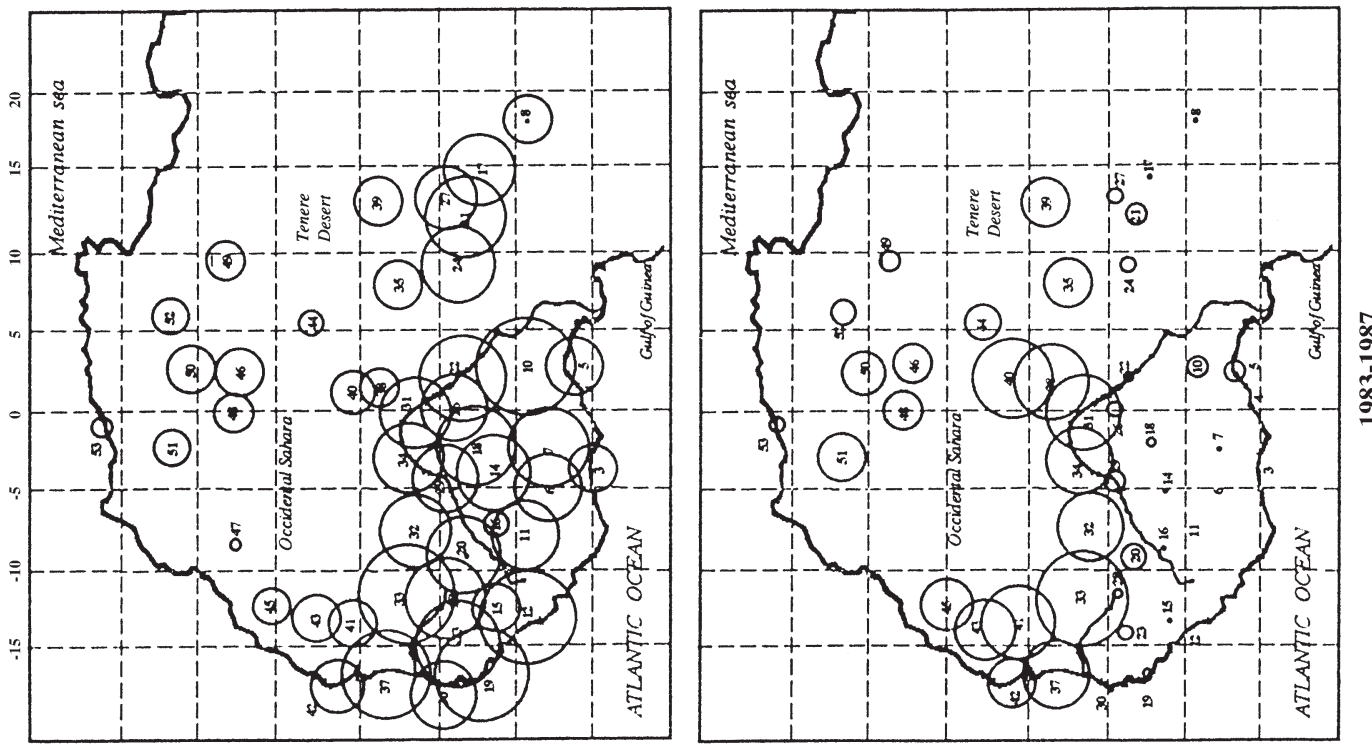

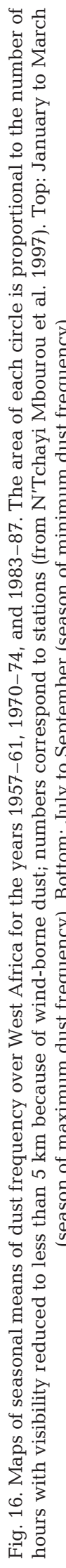
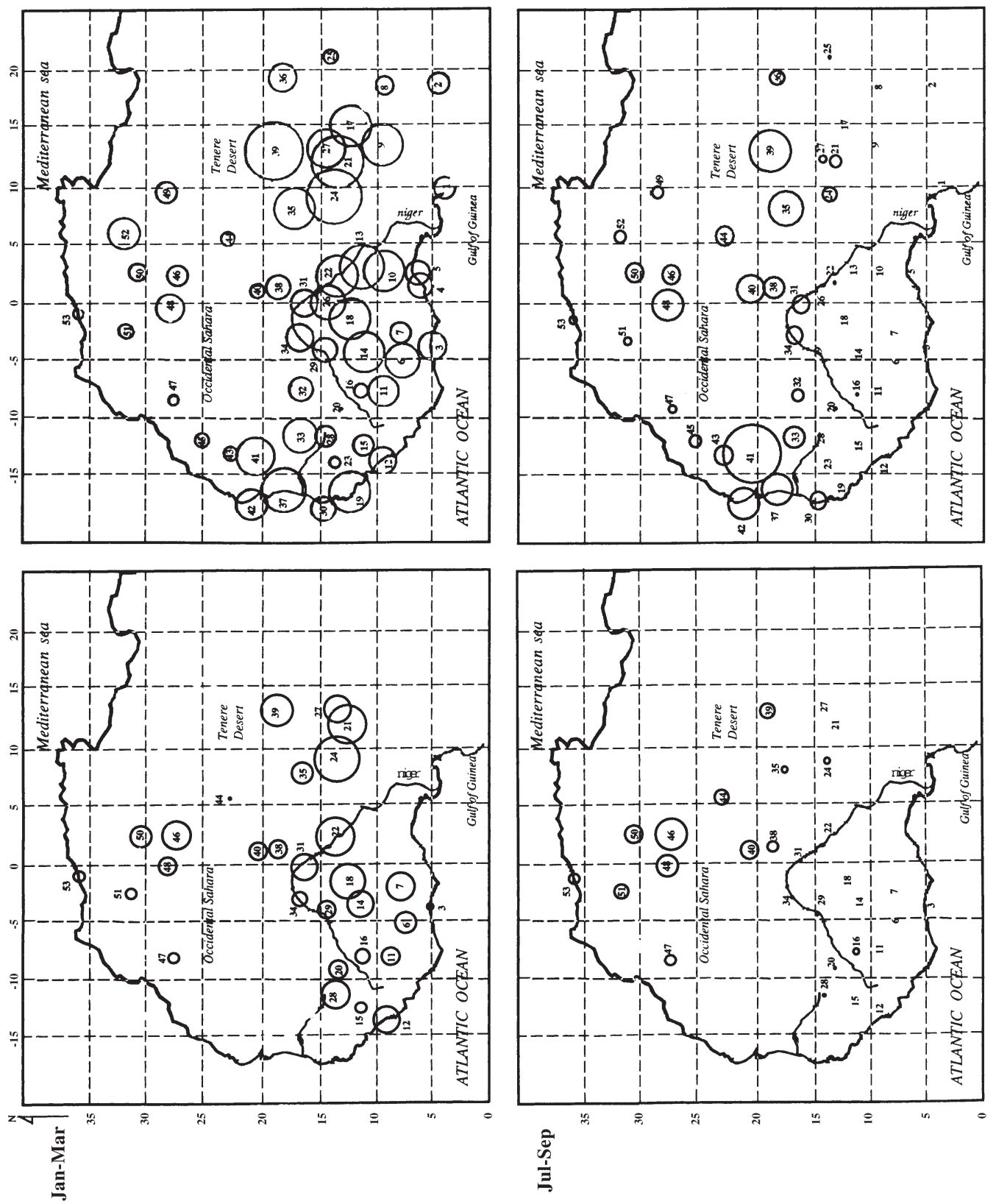


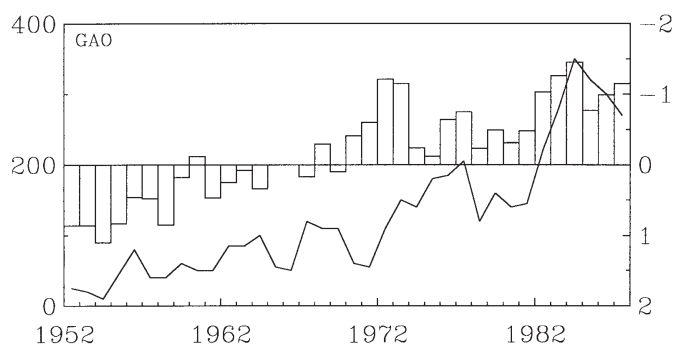

Fig. 17. Frequency of dust occurrence from 1952 to 1987 at Gao, Mali (solid line, left-hand $y$-axis) compared to rainfall anomalies (bar graph, right-hand $y$-axis) for the Sahel. Rainfall is expressed, as in Fig. 4, as a regionally averaged, standardized departure (departure from the long-term mean divided by the standard deviation), but the axis of the rainfall graph is inverted to facilitate comparison (from N'Tchayi et al. 1997)

readily apparent from simple theoretical considerations. The dust is likewise an effective absorber of longwave radiation; model results suggest that the absorption is sufficient to evoke a greenhouse-type warming of the atmosphere at least locally and thereby modify atmospheric dynamics (Andreae 1996, Tegen et al. 1996).

Observational studies of the effect of the African dust layer on heat and radiation balance were made during a field campaign in the Sahel of Niger (the ECLATS experiment) in 1980. The presence of a dust layer was shown to increase the downward infrared flux to the surface at night and to increase the radiative cooling rate of the atmosphere both near the ground and at the top of the haze layer (Guedalia et al. 1984). Consequentially, the dust reduces the diurnal temperature range by about $30 \%$ (Druilhet \& Durand 1984). The combined heating for most of the atmosphere beneath the top of the dust layer $(500 \mathrm{mb})$ was about $1 \mathrm{~K} \mathrm{~d}^{-1}$ (Carlson \& Benjamin 1980, Fouquart et al. 1987b). The dust also had a strong impact on the vertical structure of the sensible heat flux in the surface layer and on the growth of the boundary layer (Goutourbe et al. 1997).

\subsubsection{Hydrological feedbacks}

A vast number of GCM simulations of desertification and other large-scale changes of the land-surface nearly universally conclude that land surface changes can modify the large-scale precipitation field in semiarid regions such as Sahelian Africa (see review in Nicholson 2000a). Such simulations necessarily exaggerate the relevant land-surface changes and thus do not produce evidence that there have, in fact, been real effects. On the other hand, theoretical models of surface processes have placed such ideas in a more realistic framework and have helped to clarify the relevant processes of interaction. A good example is recent work on surface hydrologic processes.

Soil hydrology is essentially a low-pass filter in both time and space (Entekhabi \& Rodriguez-Iturbe 1994). Meteorological drought produces a prolonged and

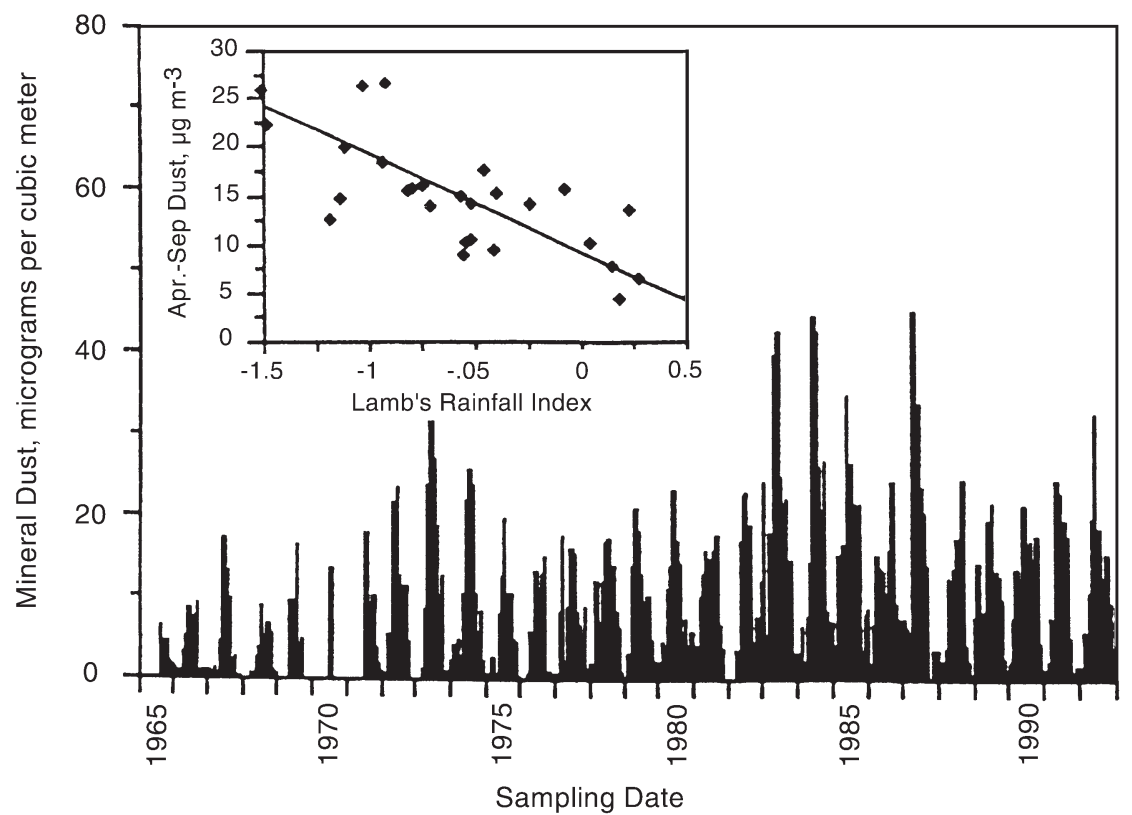

Fig. 18. Long-term (1965-92) record of monthly average atmospheric dust concentrations at Barbados (modified from Prospero 1996). A comparison with Lamb's rainfall index is given in the upper left inset 
delayed hydrologic drought that creates potential for further feedback to the atmosphere on longer time scales and larger space scales. One consequence of the various feedbacks involved is a bi-modal state of climate in semi-arid regions, in which the system locks into a drought mode and persists there for several years then slips into a persistent wet mode (Rodriguez-Iturbe et al. 1991, Entekhabi et al. 1992). Brubaker \& Entekhabi (1994) used a simple analytical model to quantify the magnitude of the feedback processes associated with the interaction between surface heat and moisture fluxes and the atmospheric boundary layer. They found that the feedback processes are positive for both wet and dry initial anomalies, but recovery from the dry state is slower than from the wet state because of the switch in the latter from soil to atmospheric control (Brubaker \& Entekhabi 1996). This is likewise consistent with observations of rainfall variability in the Sahel and in the Great Plains (Nicholson 1988, 2000a). Moreover, the magnitude of changes of surface fluxes in the Sahel during dry and wet years is sufficiently large to alter the atmospheric thermal and wind structure (Lare \& Nicholson 1994).

Some of the most interesting hydrologic results are those of Koster \& Suarez (1996), Scott et al. (1995, 1997), and Delworth \& Manabe (1993). Koster \& Suarez (1996) controlled the time scale of soil moisture retention in a GCM and found that there is greater daily precipitation variability with shorter time scales of retention. They further utilized a statistical model to explain the feedback. Scott et al. (1997) studied time scales of evapotranspiration response, showing that there is a slower response when the GCM is coupled to a bucket model than to a SVAT (soil-atmosphere transfer scheme) model. Each evaporative component (interception, soil evaporation, transpiration) has its own characteristic time scale. This is consistent with the results of Scott et al. (1995), demonstrating that the canopy interception reservoir reduces the persistence of precipitation and evaporation, in that it 'short circuits' the land surface hydrology. Delworth \& Manabe (1993) also examined time scales of soil moisture retention, showing that they correspond to a first-order Markov process with a decay time scale being equal to the ratio of field capacity to potential evapotranspiration. This result, which they had previously obtained in a theoretical study, was also demonstrated with observations.

The implications of these theoretical results are that modification of land-surface characteristics can probably alter weather patterns. Much research in the Great Plains has shown that this is unequivocally true on small scales (e.g., Barnston \& Schickedanz 1984). Elsewhere observational evidence of land-atmosphere feedback processes has been more difficult to establish. In this context, the Hydrologic-Atmospheric Pilot Experiment (HAPEX) that took place in Sahelian Africa in 1992 has produced some interesting results. For example, Wai et al. (1997) and Taylor et al. (1997) demonstrated strong contrasts in boundary layer development during the wet and dry periods. On the other hand, any variation in surface vegetation characteristics that could potentially induce variation in boundary layer characteristics appears to be overridden by the advective effects of large-scale flow patterns (Dolman et al. 1997, Taylor et al. 1997, Wai et al. 1997).

Taylor \& Lebel (1998) further used HAPEX-Sahel results to show evidence of a link between surface fluxes and persistent rainfall patterns at convective length scales. During individual rainfall events the probability of rainfall at a given location was strongly correlated with that location having received antecedent rainfall from a previous event; thus, rainfall is correlated with evaporation anomalies. This is shown by considering pairs of rain gauges within the area. After one gauge randomly receives more rainfall, a large gradient builds up as that gauge continues to receive a higher amount of rainfall during nearly all subsequent rainfall events. This phenomenon was observed at numerous pairs of gauges. In many cases, the gradient during the season was several times larger and in the opposite direction to the climatological rainfall gradient. This feedback thus enhances the patchy nature of the rainfall and creates pockets of very wet and very dry conditions within the overall rainfall field.

The theoretical and observational results described above demonstrate that surface hydrology alters the time-space structure of surface-atmosphere exchange processes, the atmospheric response and possibly the time-space structure of the precipitation field. A number of GCM experiments that explicitly treat surface hydrology have reached similar conclusions (e.g., Delworth \& Manabe 1993, Koster \& Suarez 1996, Scott et al. 1995, 1997). It has not been shown, however, that a net change in areally averaged rainfall results.

\section{SUMMARY AND CONCLUSIONS}

The most significant climatic change that has occurred in Africa has been a long-term reduction in rainfall in the semi-arid regions of West Africa. In parts of the Sahel, the most seriously affected region, $30 \mathrm{yr}$ means have decreased by 20 to $40 \%$ between the periods 1931-60 and 1968-97. Almost the entire continent has been affected by increased aridity, particularly 
since the 1980s, but it has been much more moderate in regions other than the Sahel.

The rainfall conditions over Africa during the last 2 to 3 decades are not unprecedented. A similar dry episode prevailed during most of the first half of the 19th century. By mid-century, conditions more typical of the 'normal' for the current century again prevailed. Thus, the 3 decades of dry conditions evidenced in the Sahel are not in themselves evidence of irreversible global change.

On the other hand, the processes controlling rainfall over most of the continent are now reasonably well understood. In particular, numerous studies have demonstrated that relatively warm conditions over global oceans, especially the Atlantic and Indian Oceans, tend to promote drier conditions over the continent as a whole. This is particularly true for Sahelian Africa. Thus, if a long-term trend towards higher temperatures continues over the global oceans, a scenario in which the more arid conditions continue is definitely plausible.

It has been hypothesized that anthropogenic changes of the land surface, particularly land use change and desertification, have significantly influenced rainfall. There has been speculation that this is the cause of the drier conditions in the Sahel. Current evidence suggests that the changes of the land surface that significantly impact climate (e.g., vegetation cover, surface albedo and soil moisture) are much more strongly controlled by natural climate variations, such as the recent decline in rainfall, than by humaninduced land-use change or degradation. On the other hand, there is abundant evidence that a feedback exists between the surface and the atmosphere, including the rainfall process over Africa. Thus, the potential exists for large-scale anthropogenic modification of the land surface to influence regional climates, at least in the Sahel.

Unfortunately, we still do not have any accurate large-scale assessments of the extent, nature and degree of such changes. The dreaded 'desertification' process appears to be confined to relatively small scales. However, there is still cause for concern because the net effect of the various feedback processes involved in land degradation appears to be destabilization of ecosystems, making such lands prone to increasing risk and damage (Schlesinger et al. 1990, Graetz 1991). Although deforestation is also occurring, it has similarly been difficult to produce accurate estimates of this process on large space scales (Grainger 1996). As with desertification, the potential exists for widespread deforestation to have some impact on climate, at least locally. Thus, a priority must be large-scale monitoring of the land surface and estimates of the degree of change.

\section{LITERATURE CITED}

Ahlcrona E (1988) The impact of climate and man of land transformation in central Sudan. Lund University Press, Lund

Akhtar-Schuster M (1995) Degradationsprozesse und Desertifikation im semiariden randtropischen Gebiet der Butana/ Rep. Sudan. Goettinger Beitr Land Forstwirtsch Tropen Subtropen 105

Andreae MO (1995) Climatic effects of changing atmospheric aerosols levels. In: Henderson-Sellers A (ed) World survey of climatology, Vol 16. Future climates of the world. Elsevier, Amsterdam, p 341-392

Andreae MO (1996) Raising dust in the greenhouse. Nature 380:389-390

Ba MB, Nicholson SE, Frouin R (2001) Temporal and spatial variability of surface radiation budget over the African continent as derived from METEOSAT. Part II: Temporal and spatial variability of surface global solar irradiance, albedo and net radiation. J Clim 14:60-76

Barnston AG, Schickedanz PT (1984) The effect of irrigation on warm season precipitation in the southern Great Plains. J Clim Appl Meteorol 23:865-888

ben Mohamed A, Frangi JP (1983) Humidity and turbidity parameters in Sahel: a case study for Niamey (Niger), J Clim Appl Meteorol 22:1820-1823

ben Mohamed A, Frangi JP (1986) Results from ground-based monitoring of spectral aerosol optical thickness and horizontal extinction: some characteristics of dusty Sahelian atmospheres. J Clim Appl Meteorol 25:1807-1815

ben Mohamed AJ, Frangi PJ, Fontan J, Druilhet A (1992) Spatial and temporal variations of atmospheric turbidity and related parameters in Niger. J Appl Meteorol 31: 1286-1294

Bergametti G, Gomes L, Coude-Gaussen G, Rognon P, Le Coustumer M (1989) African dust observed over Canary Islands: source-regions identification and transport pattern for some summer situations. J Geophys Res 94: 14855-14864

Biswas MK, Biswas AK (eds) (1980) Desertification. Pergamon Press, Oxford

Bradley RS, Diaz HF, Eischeid JK, Jones PD, Kelly PM, Goodess CJ (1987) Precipitation fluctuations over Northern Hemisphere land areas since the mid-19th century. Science 237:171-175

Brubaker KL, Entekhabi D (1994) Nonlinear dynamics of water and energy balance in land-atmosphere interaction. Ralph M. Parsons Lab Tech Rep No. 341, Massachusetts Institute of Technology, Cambridge, MA

Brubaker KL, Entekhabi D (1996) Asymmetric recovery from wet versus dry soil moisture anomalies. J Clim Appl Meteorol 35:94-109

Carlson TN, Benjamin SG (1980) Radiative heating rates for Saharan dust. J Atmos Sci 37:193-213

Cerf A (1980) Atmospheric turbidity over West Africa. Contrib Atmos Phys 53:414-428

Chang CB (1993) Impact of desert environment on the genesis of African wave disturbances. J Atmos Sci 50: $2137-2145$

Charney JG (1975) The dynamics of deserts and droughts. Q J R Meteorol Soc 101:193-202

Charney JG, Stone PH, Quirk WJ (1975) Drought in the Sahara: a biogeophysical feedback mechanism. Science 187:434-435

Charney JG, Quirk WJ, Chow SH, Kornfield J (1977) A comparative study of the effects of albedo change on drought in semi-arid regions. J Atmos Sci 34:1366-1385 
Courel M, Kandel R, Rasool S (1984) Surface albedo and the Sahel drought. Nature 307:528-538

d'Almeida GA (1986) A model for Saharan dust transport. J Clim Appl Meteorol 25:903-916

d'Almeida GA (1987) On the variability of desert aerosol radiative characteristics. J Geophys Res 92:3017-3026

Delworth T, Manabe S (1993) Climate variability and landsurface processes. Adv Water Resour 16:3-20

Dirmeyer PA, Shukla J (1994) Albedo as a modulator of climate response to tropical deforestation. J Geophys Res 99: 20863-20877

Dirmeyer PA, Shukla J (1996) The effect on regional and global climate of expansion of the world's deserts. Q J R Meteorol Soc 122:451-482

Dolman AJ and 6 others (1997) The role of the land surface in Sahelian climate: HAPEX-Sahel results and future research needs. J Hydrol 188-189:1067-1079

Druilhet A, Durand P (1984) Etude de la couche limite convective sahélienne en présence de brumes sèches (Expérience ECLATS). Bound Layer Meteorol 28:51-77

Duce R (1995) Sources, distributions, and fluxes of mineral aerosols and their relationship to climate. In: Charlson RJ, Heintzenberg J (eds) Dahlem Workshop on Aerosol Forcing of Climate, Berlin. John Wiley, Chichester, p 43-72

Easterling DR and 10 others (1997) Maximum and minimum temperature trends for the globe. Science 277:364-367

Entekhabi D, Rodriguez-Iturbe I (1994) An analytic framework for the characterization of the space-time variability of soil moisture. Adv Water Resour 17:35-45

Entekhabi D, Rodriguez-Iturbe I, Bras RL (1992) Variability in large-scale water balance with a land surface-atmosphere interaction. J Clim 5:798-813

Faizoun CA, Podaire A, Dedieu G (1994) Monitoring of Sahelian aerosol and atmospheric water vapor content characteristics from sun photometer measurements. J Clim Appl Meteorol 33:1291-1303

Farquharson FAK, Sutcliffe JV (1998) Regional variations of African river flows. In: Servat E, Hughes D, Fritsch JM, Hulme $M$ (eds) Water resources variability in Africa during the XXth century. IAHS publ no. 252:161-170

Folland CK, Parker DE, Ward MN, Colman AW (1991) Prediction of seasonal rainfall in the Sahel region of Africa using empirical and dynamical methods. J Forecast 10:2-56

Fouquart Y, Bonnell B, Chaoui Roquai M, Santer R (1987a) Observations of Saharan aerosols: results of ECLATS field experiment. Part I. Optical thicknesses and aerosol size distributions. J Clim Appl Meteorol 26:28-37

Feddema JJ, Freire S (2001) Soil degradation, global warming and climate impacts. In: Desanker P (ed) Africa and global climate change. CR SPECIAL 8. Clim Res 17:209-216

Fouquart Y, Bonnell B, Brogniez G, Buriez JC, Smith L, Morcrette JJ, Cerf A (1987b) Observations of Saharan aerosols: results of ECLATS field experiment. Part II. Broadband radiative characteristics of the aerosols and vertical radiative flux divergence. J Clim Appl Meteorol $26: 38-52$

Gornitz V (1985) A survey of anthropogenic vegetation changes in West Africa during the last century-climatic implications. Clim Change 7:285-325

Goutourbe JP, Noilhan J, Lacarrere P, Braud I (1997) Modelling of the atmospheric column over the Central sites during HAPEX-Sahel. J Hydrol 188-189:1017-1039

Graetz RD (1991) Desertification: a tale of two feedbacks. In: Mooney HA et al. (eds) Ecosystem experiments. John Wiley and Sons, Chichester, p 59-87

Grainger A (1996) Forest environments. In: Adams WM, Goudie AS, Orme AR (eds) The physical geography of
Africa. Oxford University Press, Oxford, p 173-195

Grove AT (1972) Climatic change in Africa in the last 20,000 years In: Les problèmes de developement du Sahara Septentrional, Ouarghla Colloquium, Algiers

Guedalia D, Estournel C, Vehil R (1984) Effects of Sahel dust layers upon nocturnal cooling of the atmosphere (ECLATS Experiment). J Clim Appl Meteorol 23:644-650

Hastenrath S (1984) The glaciers of equatorial East Africa. Kluwer, Dordrecht

Hastenrath S (1990) Decadal-scale changes of the circulation in the tropical Atlantic sector associated with Sahel drought. Int J Climatol 10:459-472

Hastenrath S, Kruss PD (1992) The dramatic retreat of Mount Kenya's glaciers between 1963 and 1987: greenhouse forcing. Ann Glaciol 16:127-133

Hastenrath S, Nicklis A, Greischar L (1993) Atmospherichydrospheric mechanisms of climate anomalies in the western equatorial Indian Ocean. J Geophys Res 98: 20219-20235

Hastenrath S, Greischar L, van Heerden J (1995) Prediction of the summer rainfall over South Africa. J Clim 8:1511-1518

Hellden U (1984) Drought impact monitoring: a remote sensing study of desertification in Kordofan, Sudan. Lunds Universitets Naturgeografiska Institution, Avhandlingar

Hellden U (1991) Desertification-time for an assessment? Ambio 20:372-383

Holben BN, Eck TF, Fraser RS (1991) Temporal and spatial variability of aerosol optical depth in the Sahel region in relationship to vegetation remote sensing. Int J Remote Sensing 12:1147-1164

Hulme M (1992) Rainfall changes in Africa: 1931-60 to 1961-90. Int J Climatol 12:685-699

Hulme M (1996) Climatic change within the period of meteorological records. In: Adams WM, Goudie AS, Orme AR (eds) The physical geography of Africa. Oxford University Press, Oxford, p 88-102

Hulme M, Doherty R, Ngara T, New M, Lister D (2001) African climate change: 1900-2100. In: Desanker P (ed) Africa and global climate change. CR SPECIAL 8. Clim Res 17:145-168

Husar RB, Prospero JM, Stower LL (1997) Characterization of tropospheric aerosols over the oceans with the NOAA advanced very high resolution radiometer optical thickness operational product. J Geophys Res 102:16889-16909

Jones PD, Lindesay J (1993) Maximum and minimum temperature trends over South Africa and the Sudan. In: Proceedings of the 4th International Conference on Southern Hemisphere Meteorology and Oceanography. American Meteorological Society, Boston, p 359-360

Jones PD, Raper SCB, Bradley RS, Diaz HF, Kelly PM, Wigley TML (1986a) Northern Hemisphere surface air temperature variations, 1851-1984. J Clim Appl Meteorol 25: 161-179

Jones PD, Raper SCB, Bradley RS, Diaz HF, Kelly PM, Wigley TML (1986b) Southern Hemisphere surface air temperature variations, 1851-1984. J Clim Appl Meteorol 25: 1213-1230

Jones PD, New M, Parker S, Martin S, Rigor IG (1999) Surface air temperature and its changes over the past 150 years. Rev Geophys 37:173-199

Karyampudi VM, Carlson TN (1988) Analysis and numerical simulations of the Saharan air layer and its effects on easterly wave disturbances. J Atmos Sci 45:3102-3136

Koster RD, Suarez JM (1996) The influence of land surface moisture retention on precipitation statistics. J Clim 9: 2551-2567

Kraus EB (1955) Secular changes of tropical rainfall regimes. 
Q J R Meteorol Soc 81:198-210

Lamb PJ (1978) Large-scale tropical Atlantic surface circulation patterns associated with Subsaharan weather anomalies. Tellus A30:240-251

Lamb PJ, Peppler RA (1992) Further case studies of tropical Atlantic surface atmospheric and oceanic patterns associated with sub-Saharan drought. J Clim 5:476-488

Lamprey H (1975) Report on the desert encroachment reconnaissance in Northern Sudan. National Council for Research/Ministry of Agriculture, Food and Natural Resources, Khartoum

Lare AR, Nicholson SE (1994) Contrasting conditions of surface water balance in wet years and dry years as a possible land surface-atmosphere feedback mechanism in the West African Sahel. J Clim 7:653-668

Legates DR, Willmott CW (1990) Mean seasonal variability in gauge-corrected, global precipitation. Int J Climatol 10: 111-127

Lézine AM (1989) Late Quaternary vegetation and climate of the Sahel. Q Res 32:317-334

Li X, Maring H, Savoie D, Voss K, Prospero JM (1996) Dominance of mineral dust in aerosol light scattering in the North Atlantic trade winds. Nature 380:416-419

Lofgren BM (1995a) Sensitivity of land-ocean circulations, precipitation, and soil moisture to perturbed land surface albedo. J Clim 8:2521-2542

Lofgren BM (1995b) Surface albedo-climate feedback simulated using two-way coupling. J Clim 8:2543-2562

Mainguet M (1991) Desertification, natural background and human mismanagement. Springer-Verlag, Berlin

Mason SJ (1995) Sea-surface temperature-South African rainfall associations, 1910-1989. Int J Climatol 15:119-135

Mason SJ, Lindesay JA, Tyson PD (1994) Simulating drought in southern Africa using sea surface temperature variation. Water SA 20:15-22

Middleton NJ, Thomas DSG (1992) World atlas of desertification. Edward Arnold, London

Nicholls NR, Gruza GV, Jouzel J, Karl TR, Ogallo LA, Parker DE (1996) Observed climate variability and change. In: Houghton JT et al. (eds) Climatic change 1995. Cambridge University Press, Cambridge, p 133-192

Nicholson SE (1978) Climatic variations in the Sahel and other African regions during the past five centuries. J Arid Environ 1:3-24

Nicholson SE (1980) Saharan climates in historic times. In: Williams MAJ, Faure H (eds) The Sahara and the Nile. AA Balkema, Rotterdam, p 173-200

Nicholson SE (1981) The historical climatology of Africa. In: Wigley TML, Ingram MJ, Farmer G (eds) Climate and history: studies on past climates and their impact on man. Cambridge University Press, Cambridge, p 249-270

Nicholson SE (1988) Land surface-atmosphere interaction: physical processes and surface changes and their impact. Prog Phys Geogr 12:36-65

Nicholson SE (1989) African drought: characteristics, casual theories and global teleconnections. In: Berger A, Dickinson RE, Kidson JW (eds) Understanding climate change. American Geophysical Union, Washington, DC, p 79-100

Nicholson SE (1990) The need for a reappraisal of the question of large-scale desertification: some arguments based on consideration of rainfall fluctuations. Report of the SAREC-Lund International Meeting on Desertification

Nicholson SE (1993) An overview of African rainfall fluctuations of the last decade. J Clim 6:1463-1466

Nicholson SE (1994) Recent rainfall fluctuations in Africa and their relationships to past conditions over the continent. The Holocene 4:121-131
Nicholson SE (1996) Environmental change within the historical period. In: Adams WM, Goudie AS, Orme AR (eds) The physical geography of Africa. Oxford University Press, Oxford, p 60-87

Nicholson SE (1997) An analysis of the ENSO signal in the tropical Atlantic and western Indian Oceans. Int J Climatol 17:345-375

Nicholson SE (1998a) Fluctuations of Rift Valley Lakes Malawi and Chilwa during historical times: a synthesis of geological, archaeological and historical information. In: Lehman JT (ed) Environmental change and response in East African lakes. Kluwer, Dordrecht, p 207-231

Nicholson SE (1998b) Historical fluctuations of Lake Victoria and other lakes in the northern Rift Valley of East Africa. In: Lehman JT (ed) Environmental change and response in East African lakes. Kluwer, Dordrecht, p 7-35

Nicholson SE (1999) Historical and modern fluctuations of Lakes Tanganyika and Rukwa and their relationship to rainfall variability. Clim Change 41:53-71

Nicholson SE (2000a) Land surface processes and Sahel climate. Rev Geophys 38:117-139

Nicholson SE (2000b) A semi-quantitative, regional precipitation data set for studying African climates of the nineteenth century, Part I. Overview of the data set. Clim Change (in press)

Nicholson SE, Entekhabi D (1986) The quasi-periodic behavior of rainfall variability in Africa and its relationship to the Southern Oscillation. Arch Meteorol Geophys Bioclimatol Ser A 34:311-348

Nicholson SE, Kim J (1997) Relationship of ENSO to African rainfall. Int J Climatol 17:117-135

Nicholson SE, Selato JC (2000) The influence of La Niña on African rainfall. Int J Climatol 20:1761-1776

Nicholson SE, Yin X (2001) Rainfall conditions in equatorial East Africa during the nineteenth century as inferred from the record of Lake Victoria. Clim Change 48:387-398

Nicholson SE, Tucker CJ, Ba MB (1998) Desertification, drought and surface vegetation: an example from the West African Sahel. Bull Am Meteorol Soc 79:815-829

Nicholson SE, Some B, Kone B (2000) A note on recent rainfall conditions in West Africa, including the rainy season of the 1997 El Niño year. J Clim 13:2628-2640

Norton CC, Mosher FR, Hinton B (1979) An investigation of surface albedo variations during the recent Sahel drought. J Clim Appl Meteorol 18:1252-1262

N'Tchayi Mbourou G, Bertrand J, Legrand M, Baudet J (1994) Temporal and spatial variations of the atmospheric dust loading throughout West Africa over the last thirty years. Ann Geophys 12:265-273

N'Tchayi Mbourou G, Bertrand J, Nicholson SE (1997) The diurnal and seasonal cycles of wind-borne dust over Africa north of the equator. J Clim Appl Meteorol 36:868-882

Olsson L (1985) An integrated study of desertification. Lunds Universitets Geografiska Institution, Avhandlingar

Oluwafemi CO (1979) Preliminary solar spectro-photometric measurements of aerosol optical density at Lagos, Nigeria. Atmos Environ 13:1611-1615

Otterman J (1974) Baring high-albedo soils by overgrazing: a hypothesized desertification mechanism. Science 186: 531-533

Otterman J (1977) Anthropogenic impact on the albedo of the Earth. Clim Change 1:137-157

Otterman J (1981) Satellite and field studies of man's impact on the surface in arid regions. Tellus 33:68-77

Pinker RT, Idemudia G, Aro TO (1994) Characteristic aerosol optical depths during the Harmattan season in subSaharan Africa. J Geophys Res 21:685-688 
Prince SD, Brown de Colstoun E, Kravitz LL (1998) Desertification of the Sahel? Evidence from remotely sensed rainuse efficiencies. Global Change Biol 4:359-374

Prospero JM (1996) The atmospheric transport of particles to the ocean. In: Ittekkot V, Schafer P, Honjo S, Depetris PJ (eds) Particle flux in the ocean. SCOPE Report 57, John Wiley and Sons, Chichester, p 19-52

Prospero JM, Nees RT (1986) Impact of the North African drought and El Niño on mineral dust in the Barbados trade winds. Nature 320:735-738

Prospero JM, Savoie DL, Arimoto R, Huang F (1993) Longterm trends in African mineral dust concentrations over the western North Atlantic: relationship to North African rainfall. EOS Trans AGU 74(43):146

Puigdefabregas J (1995) Desertification: stress beyond resilience, exploring a unifying process structure. Ambio 24: 311-313

Rocha A, Simmonds I (1996) Interannual variability of southern African summer rainfall. Part I: Relationships with airsea interaction processes. Int J Climatol 17:235-266

Rodriguez-Iturbe I, Entekhabi D, Bras RL (1991) Nonlinear dynamics of soil moisture at climate scales: 1 . Stochastic analysis. Water Resour Res 27:1899-1906

Schlesinger WH, Reynolds JF, Cunningham GL, Huenneke LF, Jerrell WM, Virginia RA, Whitford WG (1990) Biological feedbacks in global desertification. Science 247: 1043-1048

Schwarz EHL (1920) The Kalahari or Thirstland Redemption. T Maskew Miller, Capetown

Scott R, Koster R, Entekhabi D, Suarez M (1995) Effect of a canopy interception reservoir on hydrological persistence in a general circulation model. J Clim 8:1917-1922

Scott R, Entekhabi D, Koster R, Suarez M (1997) Timescales of land surface evapotranspiration response. J Clim 10: 559-566

Shaw P (1985) The desiccation of Lake Ngami: an historical perspective. Geogr J 151:318-326

Sud YC, Fennessy MJ (1982) A study of the influence of surface albedo on July circulation in semiarid regions using the GLASS GCM. J Climatol 2:105-125

Sud YC, Molod A (1988) A GCM simulation study of the influence of Saharan evapotranspiration and surface-albedo anomalies on July circulation and rainfall. Mon Weather Rev 116:2388-2400

Sutcliffe JV, Knott DG (1987) Historical variations in African water resources. The influence of climatic change and climatic variability on the hydrologic regime and water resources. IAHS publ no. 168:463-475

Taylor CM, Lebel T (1998) Observational evidence of persistent convective scale rainfall patterns. Mon Weather Rev 126:1597-1607

Taylor CM, Harding RJ, Thorpe AJ, Bessemoulin P (1997) A mesoscale simulation of land surface heterogeneity from HAPEX-Sahel. J Hydrol 188-189:1040-1066

Tegen I, Fung I (1994) Modeling of mineral dust in the atmosphere: sources, transport, and optical thickness. J Geophys Res 99:22897-22914

Tegen I, Fung I (1995) Contribution to the atmospheric mineral aerosol load from land surface modification. J Geophys Res 100:18707-18726

Tegen I, Lacis AA, Fung I (1996) The influence of mineral aerosols from disturbed soils on the global radiation budget. Nature 380:419-422

Thomas DSG, Middleton NJ (1994) Desertification: exploding the myth. John Wiley and Sons, Chichester

Tucker CJ, Nicholson SE (1998) Variations in the size of the Sahara desert from 1980 to 1997. Ambio 28(2):587-591

Tucker CJ, Dregne HE, Newcomb WW (1998) Expansion and contraction of the Sahara desert from 1980 to 1990. Science 253:299-301

Verstraete MM (1986) Defining desertification: a review. Clim Change 9:5-18

Wagner RG, da Silva A (1994) Surface conditions associated with anomalous rainfall in the Guinea coastal region. Int $\mathrm{J}$ Climatol 14:179-199

Wai MMK, Smith EA, Bessemoulin P, Culf AD, Dolman AJ, Lebel T (1997) Variability in boundary layer structure during HAPEX-Sahel wet-dry season transition. J Hydrol 188-189:965-997

Walling DE (1996) Hydrology and rivers. In: Adams WM, Goudie AS, Orme AR (eds) The physical geography of Africa. Oxford University Press, Oxford, p 103-121

Ward NM (1998) Provisionally corrected surface wind data, world-wide ocean-atmosphere surface fields, and Sahelian rainfall variability. J Clim 5:454-475

Warren A (1996) Desertification. In: Adams WM, Goudie AS, Orme AR (eds) The physical geography of Africa. Oxford University Press, Oxford, p 342-355

Wendler G, Eaton F (1983) On the desertification in the Sahel zone. Part I. Ground observations. Clim Change 5: 365-380

Xue Y, Shukla J (1993) The influence of land surface properties on Sahel climate: Part I. Desertification. J Clim 6: $2232-2345$ 